\title{
USE OF MAGNETIZED WATER AND COMPOST TEA TO IMPROVE PEACH PRODUCTIVITY UNDER SALINITY STRESS OF NORTH SINAI CONDITIONS, EGYPT
}

\author{
Sheren A. Abd El-Hamied* and Wael M. Ghieth \\ Department of Plant Production, Desert Research Center, Cairo, Egypt \\ *Email: sherenadel3m@yahoo.com
}

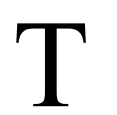

his study was conducted during two successive seasons (2015 and 2016) at El-Sheikh Zuwayid, North Sinai Governorate, Egypt. The aim of this research was to investigate the effect of electromagnetic device and compost tea with or without some natural growth stimulants on growth and productivity of Sweet Sheikh Zuwayid peach cultivar (Prunus persica L.) under salinity stress. In this experiment, there was two irrigation water types (i.e., magnetized water (MW), and non-magnetized water (NMW)). Besides spraying with compost tea (as a natural growth stimulants), as follows: $\mathrm{T}_{1}$ : spraying with water + molasses as a control treatment, $\mathrm{T}_{2}$ : compost tea + molasses, $\mathrm{T}_{3}$ : compost tea + licorice extract + molasses, $\mathrm{T}_{4}$ : compost tea + moringa extract + molasses, and $\mathrm{T}_{5}$ : compost tea + algae extract + molasses. Investigated trees sprayed with $1.5 \mathrm{~L}$ four times along each season (at full bloom, fruit set, after one month later from fruit set and after two months later from fruit set). The obtained results revealed that all treatments were very effective in stimulating growth parameters, mineral contents, yield, physical and chemical characteristics of the fruits, water properties and soil properties. Generally, magnetized water (MW) was better than non-magnetized water (NMW) in all parameters. In addition, $\mathrm{T}_{3}$ under $\mathrm{MW}$ increased shoot length, number of leaves/shoot, leaf area, leaf mineral contents $(\mathrm{N}, \mathrm{P}, \mathrm{K}, \mathrm{Fe}$, $\mathrm{Zn}, \mathrm{Cu}$ and $\mathrm{Mg}$ ), fruit length, fruit diameter, fruit volume, fruit weight, flesh weight, fruit flesh ratio, yield, total soluble solids and total sugar content, and decreased total acidity content. Furthermore, there was a slight change in water-soluble salts, $\mathrm{pH}$, micronutrients and salts composition when irrigation water conducted to magnetic field. Generally, it clearly appears that $\mathrm{EC}, \mathrm{pH}, \mathrm{Ca}, \mathrm{Mg}, \mathrm{K}$ and $\mathrm{Na}$ in the soil decreased, when irrigated with 
magnetized water, while $\mathrm{Fe}, \mathrm{Zn}, \mathrm{Cu}$ and $\mathrm{Mn}$ in the soil increased.

Keywords: peach, salinity stress, magnetized water, compost tea, licorice extract, moringa extract, algae extract, North Sinai

Peach (Prunus persica L.) belonging to the family Rosaceae is an important stone fruit grown in temperate and subtropical regions of the world. In Egypt, North Sinai is one of the focus points of peach production.

The increase of the groundwater salinity at several regions resulted in big chronic problems in the availability of irrigation water suitable for agriculture in the Egyptian deserts. Therefore, the importance of physical treatment of saline water using magnetic devices becomes feasible. Magnetically treated water (MTW) is considered as environmentally friendly technique (Nimmi and Medhu, 2009). MTW is produced when water passes through the magnetic field of the permanent electromagnetic device, installed on feed pipeline, where all water and salt molecules have the internal vibration (Babu, 2010). The irrigation with magnetized water significantly increased the plant characteristics, chemical composition and availability of nutrients in the soil, as well as the increments of total yield. However, the mechanism of action of magnetic field treatment in the plants is still unknown until now, but several theories have been proposed to explain this action, i.e.;

1. The mechanism of magnetic field is associated with the activation of phytohormone such as gibberellic acid-equivalents, indole-3-acetic acid and trans-zeatin as well as activation of the bio-enzyme systems (Maheshwari and Grewal, 2009 and Hozayn and Abdul Qados, 2010).

2. The modification of rate of ion transport across the plasma membrane or otherwise affect the structure of cell membrane lipid protein dynamics may cause the alteration in the permeability of the plasma membrane of plant roots (Stange et al., 2002).

3 . In the same manner, the variations induced by magnetic fields in the ionic currents across the cellular membrane leads to change in the osmotic pressure and significant increase in the rate of water absorption (Taia et al., 2007). MTW removes the excess of the soluble salts; reduces $\mathrm{pH}$ values, due to that MTW solves soil salts and leaches them away from the roots zone (Hilal et al., 2012). In addition, Selim (2008) stated that MTW has induced changes in the mobility of nutrient elements in root zone, which differences from one element to another according to the element magnetic susceptibility. Using MTW improved the crop yield and increases the productivity of water unit and save water supply, especially with the future water scarcity as mentioned by Hilal et al. (2012) and Fanous et al.(2017).

Compost tea is becoming increasingly popular amendment in organic agriculture, which is simply liquid solution form compost that has been 
soaked in water. Researches had documented that compost tea suppresses diseases in the organic systems, thought to increase aggregate stability, produces convert organic matters partially or into available nutrients, plant hormones, mineralize plant available nutrients, fixes nitrogen and providing useful microorganisms. Many investigators reported similar promotion effect of compost fertilizer on different plants such as El-Sherbeny et al. (2007) on Ruta graveolens and Hendawy (2008) on Plantago arenaria.

Licorice (Glycyrrhiza glabra) family Leguminoseae, is a plant which grows in Egypt and some other countries of the world. Its roots possess some nutritive value and medicinal properties, so, it is widely used as a cold beverage and in preparing some pharmaceutical agents (Fenwick et al., 1990). The licorice extract contains more than 100 various compounds, which some of them accumulate in large amounts. The most important of the compounds are triterpene saponins (including glycyrrhizin) and phenolic compounds (Shibata, 2000 and Shabani et al., 2009). In addition, licorice extract contain protein and amino acid (Asparagin), monosaccharide (glucose, fructose, sucrose and maltose), lignins, tannins, starch, choline, phytosterols, different types of vitamins such as B1, B2, B3, B6, C, E, biotin, folic acid, pantothenic acid, many mineral compounds (aluminum, calcium, iron, magnesium, cobalt, zinc, phosphorus, sodium, silicone, potassium and stannous) and bitter principles (Fukai et al., 1998 and Arystanova et al., 2001). Moreover, Qaraghouli and Jalal (2005) found that spraying apple with licorice and garlic extracts gave the highest value in yield and fruit quality in addition to improve all growth parameters. Hussein (2008) found that spraying date palm with licorice extract at $5 \mathrm{~g} / \mathrm{L}$ increased the fruit quality.

Moringa oleifera (family: Moringaceae) is one of such alternatives, being investigated to ascertain its effect on growth and yield of crops and thus can be promoted among farmers as a possible supplement or substitute to inorganic fertilizers (Phiri, 2010). Fresh Moringa oleifera content of proteins, vitamins (such as A, B1, B2, B3, ascorbic acid and E), $\beta$ carotene, amino acids, phenolic compounds, sugars and minerals (such as calcium, magnesium, sodium, iron, phosphorus, and potassium) (Fuglie, 2000; Foidl et al., 2001 and Nagar et al., 2006). Moringa leaf extract that sprayed onto leaves $(25 \mathrm{ml})$ of onions, bell pepper, soya beans, sorghum, coffee, tea, chili, melon, and maize was shown to increase yields of these crops (Fuglie, 2000).

Algae extract has a positive effect on plant growth, yield and fruit quality (Jaswant et al., 1994 and Hegab et al., 2005). Algae extract (as a new bio-fertilizer), containing $\mathrm{N}, \mathrm{P}, \mathrm{K}, \mathrm{Ca}, \mathrm{Mg}$, and $\mathrm{S}$ as well as $\mathrm{Zn}, \mathrm{Fe}, \mathrm{Mn}, \mathrm{Cu}$, $\mathrm{Mo}$, and $\mathrm{Co}$, some growth regulators, polyamines and vitamins is applied to improve nutritional status, vegetative growth in different orchard such as vineyards (Eman and Abd-Allah, 2008 and Elham et al., 2010). Chouliaras et al. (2009) recommended the combination of $\mathrm{NH}_{4} \mathrm{NO}_{3}+$ borax + seaweed 
extract in order to improve growth and nutrition status of the Koroneiki cultivar olive (Olea europaea L.). Mansour et al. (2006) investigated the impact of algae extract application to Anna apple trees and found that it was very effective in stimulating the leaf mineral content.

The aim of this study was to investigate the effect of irrigation with water subjected to electromagnetic fields, irrigation with normal water and with or without some natural growth stimulants; on growth and productivity of Sweet Sheikh Zuwayid peach cultivar (Prunus persica L.) under salinity stress, in addition to their effect on the soil properties.

\section{MATERIALS AND METHODS}

This study was conducted during the two successive seasons of 2015and 2016 at El-Sheikh Zuwayid, North Sinai Governorate, Egypt, on 60 trees of the Sweet Sheikh Zuwayid peach cultivar (Prunus persica L.) grafted on almond rootstock. The trees were 10 years old, planted at $5 \times 5 \mathrm{~m}$ apart, and grown in sandy soil under drip irrigation system. All trees are almost uniform in shape and received the common horticultural practices. The soil and irrigation water analysis data are given in table (1). The magnetized irrigation water was obtained by passing irrigation water through the electromagnetic device installed on the main irrigation pipes of the experimental area of the orchard (EWN Sharaf-1 device, from ITEN Company, Egypt; 220V. 50 CIS or 12 V.D.C. and power consumption 2.4 W/unit)

Table (1). Some physical and chemical properties of the experimental soil and irrigation water.

\begin{tabular}{|c|c|c|c|c|c|}
\hline Characteristics & Soil & Water & Characteristics & Soil & Water \\
\hline Particle size distribution (\%) & & & \multicolumn{3}{|c|}{ Soluble anions (meq/L) } \\
\hline sand & 93.30 & & & & \\
\hline silt & 4.90 & & & & \\
\hline clay & 2.10 & & & & \\
\hline Texture class & sandy soil & & & & \\
\hline $\mathrm{SP}$ & 19.50 & 6.60 & $\mathrm{CO}_{3}^{-2}$ & --- & -- \\
\hline $\mathrm{EC}\left(\mathrm{dsm}^{-1}\right)$ & 4.29 & 2.13 & $\mathrm{HCO}_{3}^{-}$ & 3.1 & 1.6 \\
\hline $\mathrm{pH}$ & 8.00 & 8.00 & $\mathrm{Cl}^{-}$ & 25.6 & 16.3 \\
\hline $\mathrm{SP} \%$ & 19.50 & 6.60 & $\mathrm{SO}_{4}^{-2}$ & 14.2 & 3.4 \\
\hline Soluble cations (meq/L) & & & \multicolumn{3}{|c|}{ Available micronutrients in soil (ppm) } \\
\hline $\mathrm{Ca}^{+2}$ & 20.00 & 6.00 & $\mathrm{Fe}$ & 2.8 & 1.4 \\
\hline $\mathrm{Mg}^{+2}$ & 7.80 & 1.30 & $\mathrm{Zn}$ & 3.6 & 1.4 \\
\hline $\mathrm{Na}^{+}$ & 14.10 & 13.60 & $\mathrm{Cu}$ & 0.7 & 0.2 \\
\hline $\mathrm{K}^{+}$ & 1.00 & 0.40 & $\mathrm{Mn}$ & 5.4 & 0.1 \\
\hline
\end{tabular}

Egyptian J. Desert Res., 67, No. 2, 231-254 (2017) 
Preparing the compost tea of different sources, and all of the other extracts (i.e,. licorice, moringa and algae) was carried out prior the begging of each spraying time (at full bloom, fruit set, one month later from fruit set and after two months later from fruit set). The procedure of preparing the mentioned materials (compost tea and the other extracts) could be described as follow:

\section{EI Nile Compost Tea}

Compost tea (Table 2) was prepared by soaking compost in water (1: $4 \mathrm{w} / \mathrm{w}$ ) according to Said et al. (2010). Compost was mixed in a large plastic barrel to ensure a homogeneous mix. The compost was kept in a refrigerated condition to maintain consistent tea production by slowing microbial activity with the help of molasses substance as $100 \mathrm{ml} / \mathrm{L}$. Prior to brewing, the compost was put through a $0.64 \mathrm{~cm}$ sieve to remove any unnecessary large fragments. The compost tea was brewing for 48 hours.

Table (2). The physicochemical properties and microbial population of organic compost tea.

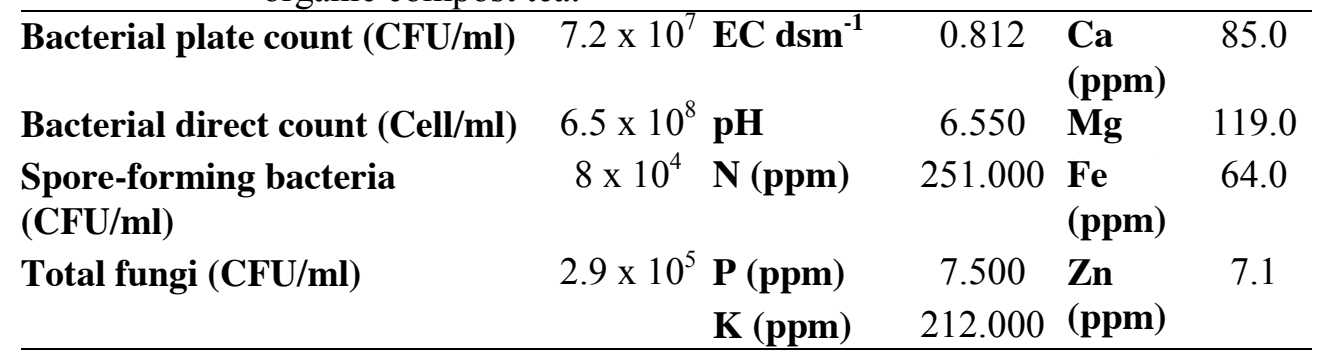

\section{Licorice Roots Extract}

The aqueous extract of licorice roots (Glycyrrhiza glabra) (Table 3) was prepared by boiling $2 \mathrm{~g}$ in one liter of distilled water for 15 minutes. The solution filtered using a cotton cloth, and re-filtered through Whatman filter paper No. 2 and completed by distilled water to one liter.

Table (3). The physicochemical properties of Licorice extracted (in dry matter).

\begin{tabular}{lllclc}
\hline Reducing sugar (\%) & 3.23 & Humidity (\%) & 5.88 & $\mathbf{C a}(\mathbf{m g} / \mathbf{g})$ & 560.0 \\
Non-reducing sugar (\%) & 10.27 & $\mathbf{G A}_{\mathbf{3}}(\%)$ & 0.63 & $\mathbf{M g}(\mathbf{m g} / \mathbf{g})$ & 280.0 \\
Starch (\%) & 4.76 & $\mathbf{P}(\mathbf{m g} / \mathbf{g})$ & 540.00 & $\mathbf{F e}(\mathbf{m g} / \mathbf{g})$ & 33.0 \\
Ash (\%) & 10.55 & $\mathbf{K}(\mathbf{m g} / \mathbf{g})$ & 1235.00 & $\mathbf{Z n}(\mathbf{m g} / \mathbf{g})$ & 3.6 \\
Glycyrrhizic acid (\%) & 26.00 & & & & \\
\hline
\end{tabular}




\section{Moringa Extract}

The moringa extract (Table 4) was prepared by blending $2 \mathrm{~g}$ of young moringa leaves with $675 \mathrm{ml}$ of $80 \%$ ethanol as suggested by Makkar and Becker (1996). The obtained suspension homogenized and filtered using a cotton cloth. Finally, the solution re-filtered using Whatman filter paper No. 2 and rose to one liter.

Table (4). Chemical components and amino acid composition of moringa leaves extracted according to Mona (2013).

\begin{tabular}{lclc}
\hline $\begin{array}{l}\text { Chemical } \\
\text { components } \\
\text { extracted }\end{array}$ & $(g / \mathbf{1 0 0}$ g. d. wt.) & $\begin{array}{l}\text { Chemical } \\
\text { components } \\
\text { extracted }\end{array}$ & $(\mathbf{g} / \mathbf{1 0 0}$ g.d.wt. $)$ \\
\hline Water & 5.9 & $\mathbf{C a}$ & 2.000 \\
Protein & 27.2 & $\mathbf{M g}$ & 0.370 \\
Lipids & 17.1 & $\mathbf{K}$ & 0.013 \\
Total sugars & 38.6 & $\mathbf{F e}$ & 0.028 \\
Fiber & 19.2 & $\mathbf{P}$ & 0.200 \\
\hline
\end{tabular}

\section{Algae Extract}

Algae extract physicochemical properties are shown in table (5). It was used as $2 \mathrm{~g} / \mathrm{L}$ concentration (as recommended by the producing company). Triton B at $0.1 \%$ was used as wetting agents with all treatments, except with Glycyrrhiza glabra extract that contains saponin triterpenes.

Table (5). The physicochemical properties of algae.

\begin{tabular}{ccccccc}
\hline $\begin{array}{c}\text { Oligosaccharide } \\
(\%)\end{array}$ & $\begin{array}{c}\text { Alginic } \\
\text { acid (\%) }\end{array}$ & $\begin{array}{c}\text { Phytin } \\
(\boldsymbol{\%})\end{array}$ & $\begin{array}{c}\text { Menthol } \\
(\boldsymbol{\%})\end{array}$ & $\begin{array}{c}\text { Natural growth regulators } \\
\text { Cytokinin } \\
(\boldsymbol{\%})\end{array}$ & $\begin{array}{c}\text { Indol acetic } \\
\text { acid (\%) }\end{array}$ & $\begin{array}{c}\text { Pepsin } \\
(\boldsymbol{\%})\end{array}$ \\
\hline 3 & 5 & 0.003 & 0.001 & 0.001 & 0.0002 & 0.02 \\
\hline Minerals & $\mathbf{K}$ oxide & $\mathbf{P ~ o x i d e ~}$ & $\mathbf{N}$ & $\mathbf{Z n}$ & $\mathbf{F e}$ & $\mathbf{M n}$ \\
& $(\boldsymbol{\%})$ & $(\boldsymbol{\%})$ & $(\boldsymbol{\%})$ & $(\boldsymbol{\%})$ & $(\%)$ & $(\%)$ \\
\hline & 12 & 0.5 & 1 & 0.3 & 0.2 & 0.2 \\
\hline
\end{tabular}

The ratio of mixing the spraying solutions was four volumes of compost tea plus one volume of the other extracts in addition to molasses $(100 \mathrm{ml} / \mathrm{L})$. The experiments work arrangement in factorial design with two irrigation water types (i.e., magnetized water (MW), and nonmagnetized water (NMW) and the sub-main factor was spraying with different sources of compost tea, as follows: $\mathrm{T}_{1}$ : control treatment (spraying with water + molasses $(100 \mathrm{ml} / \mathrm{L})), \mathrm{T}_{2}$ : El Nile compost tea + molasses $(100$ $\mathrm{ml} / \mathrm{L}), \mathrm{T}_{3}$ : El Nile compost tea + licorice extract $(4: 1, \mathrm{v}: \mathrm{v})+$ molasses $(100$ $\mathrm{ml} / \mathrm{L}), \mathrm{T}_{4}$ : El Nile compost tea + moringa extract $(4: 1, \mathrm{v}: \mathrm{v})+$ molasses $(100$ $\mathrm{ml} / \mathrm{L})$ and $\mathrm{T}_{5}$ : El Nile compost tea + algae extract $(4: 1, \mathrm{v}: \mathrm{v})+$ molasses $(100$ $\mathrm{ml} / \mathrm{L}$ ). Each tree was sprayed with $1.5 \mathrm{~L}$. 
The following parameters were measured for both seasons:

a. Shoot length and number of leaves/shoot: at the end of each season (first week of October).

b. Leaf area $\left(\mathbf{c m}^{2}\right)$ : was determined by using the leaf area meter CL203.

c. Macro and micronutrients: Leaves samples were collected at the end of June 2015 and then dried at $70^{\circ} \mathrm{C}$ in a hot air oven. The dried samples were ground and then digested for nitrogen, phosphorus and potassium analyses. Nitrogen was determined by micro-Kjeldahl method, Phosphorus was estimated colorimetrically using ascorbic acid and ammonium molybdate using spectrophotometer and potassium was measured using flame photometer according to Page et al. (1982). Total iron, zinc, copper and manganese contents were determined by using Atomic Absorption Spectrophotometer, Pye unican SP1900, according to Brandifeld and Spincer (1965).

d. The tree yield $(\mathrm{kg} / \mathrm{tree})$ was recorded

e. Fruit parameters (fruit physical characteristics): Fruits sample were taken at the harvest time to be used for determining the physical properties (i.e., fruit length $(\mathrm{cm})$, fruit diameter $(\mathrm{cm})$ and fruit weight $(\mathrm{g})$, fruit volume $\left(\mathrm{cm}^{3}\right)$, flesh weight and fruit flesh ratio\% (flesh weight/fruit weight).

f. Fruit quality (fruit chemical characteristics): a sample of 10 mature fruits of each tree was taken at the harvest time to be used for determining the chemical properties i.e., the total soluble solids percentage (T.S.S.\%) was measured by using a hand refractometer and the acidity \% as citric acid content using fresh juice with titration against $0.1 \mathrm{NaOH}$. The total sugars $\%$ according to A.O.A.C (1985) was determined.

g. Soil and water nutrient contents: Before applying the treatments and at the end of experiment of work, soil samples were taken from each treatment at major root zone (0-60 cm depth). Soil samples were prepared for analysis according to Jackson (1967). These soil samples were dried, sieved (through $2 \mathrm{~mm}$ ) and analyzed for soluble cations, soluble anions and available micronutrients in soil. In addition, water samples were taken from MW and NMW to be examined as discussed by Page et al. (1982).

\section{Statistical Analysis}

The obtained data were subjected to analysis of variance according to Clarke and Kempson (1997). Means were differentiated using Range test at the 0.05 level (Duncan, 1955).

\section{RESULTS AND DISCUSSION}

\section{Shoot Length, Number of Leaves/Shoot and Leaf Area}

Data in table (6), clear that shoot length, the number of leaves/shoot and leaf area were significantly affected by all treatments in both seasons. However, MW gave the best shoot length $\left(26.27 \mathrm{~cm}\right.$ in the $1^{\text {st }}$ and $27.83 \mathrm{~cm}$ 
in the $2^{\text {nd }}$ season $)$, number of leaves/shoot $\left(20.00\right.$ in the $1^{\text {st }}$ and 21.13 in the $2^{\text {nd }}$ season $)$ and leaf area $\left(19.88 \mathrm{~cm}^{2}\right.$ in the $1^{\text {st }}$ and $20.24 \mathrm{~cm}^{2}$ in the $2^{\text {nd }}$ season) comparing with NMW.

Table (6). Effect of magnetized water and compost tea on some peach growth parameters during 2015 and 2016 seasons.

\begin{tabular}{|c|c|c|c|c|c|c|c|}
\hline & & \multicolumn{2}{|c|}{ Shoot length $(\mathrm{cm})$} & \multicolumn{2}{|c|}{$\begin{array}{l}\text { Number of } \\
\text { leaves/shoot }\end{array}$} & \multicolumn{2}{|c|}{ Leaf area $\left(\mathrm{cm}^{2}\right)$} \\
\hline & & $\begin{array}{l}\text { Season } \\
2015\end{array}$ & $\begin{array}{l}\text { Season } \\
2016\end{array}$ & $\begin{array}{l}\text { Season } \\
2015\end{array}$ & $\begin{array}{c}\text { Season } \\
2016\end{array}$ & $\begin{array}{l}\text { Season } \\
2015\end{array}$ & $\begin{array}{c}\text { Season } \\
2016\end{array}$ \\
\hline \multicolumn{8}{|c|}{ Effect of water } \\
\hline MW & & $26.27 \mathrm{a}$ & $27.83 a$ & $20.00 \mathrm{a}$ & $21.13 \mathrm{a}$ & $19.88 \mathrm{a}$ & $20.24 a$ \\
\hline NMW & & $20.71 \mathrm{~b}$ & $22.13 b$ & $15.73 b$ & $15.93 b$ & $15.79 b$ & $15.16 \mathrm{~b}$ \\
\hline \multicolumn{8}{|c|}{ Effect of compost tea with or without some growth stimulants } \\
\hline $\mathrm{T}_{1}$ & & $21.21 \mathrm{e}$ & $22.62 \mathrm{e}$ & $16.00 \mathrm{e}$ & $16.33 \mathrm{e}$ & $16.35 \mathrm{~d}$ & $15.40 \mathrm{e}$ \\
\hline $\mathrm{T}_{2}$ & & $22.30 \mathrm{~d}$ & $23.82 \mathrm{~d}$ & $16.66 \mathrm{~d}$ & $17.50 \mathrm{~d}$ & $16.72 \mathrm{~cd}$ & $16.77 \mathrm{~d}$ \\
\hline $\mathrm{T}_{3}$ & & $25.84 \mathrm{a}$ & $27.23 \mathrm{a}$ & $19.83 \mathrm{a}$ & $20.66 \mathrm{a}$ & $19.27 \mathrm{a}$ & $19.79 \mathrm{a}$ \\
\hline $\mathrm{T}_{4}$ & & $24.85 b$ & $26.09 b$ & $19.00 \mathrm{~b}$ & $19.66 \mathrm{~b}$ & $18.97 \mathrm{ab}$ & $18.81 \mathrm{~b}$ \\
\hline $\mathrm{T}_{5}$ & & $23.25 \mathrm{c}$ & $25.13 \mathrm{c}$ & $17.83 \mathrm{c}$ & $18.50 \mathrm{c}$ & $17.85 \mathrm{bc}$ & $17.74 \mathrm{c}$ \\
\hline \multicolumn{8}{|c|}{ Effect of interaction between water and compost tea treatments } \\
\hline \multirow{2}{*}{ Water } & \multirow{2}{*}{$\begin{array}{l}\text { Compost } \\
\text { tea }\end{array}$} & \multicolumn{2}{|c|}{$\begin{array}{c}\begin{array}{c}\text { Shoot length } \\
(\mathrm{cm})\end{array} \\
\end{array}$} & \multicolumn{2}{|c|}{$\begin{array}{c}\text { Number of } \\
\text { leaves/shoot }\end{array}$} & \multicolumn{2}{|c|}{ Leaf area $\left(\mathrm{cm}^{2}\right)$} \\
\hline & & $\begin{array}{c}\text { Season } \\
2015\end{array}$ & $\begin{array}{c}\text { Season } \\
2016\end{array}$ & $\begin{array}{c}\text { Season } \\
2015\end{array}$ & $\begin{array}{c}\text { Season } \\
2016\end{array}$ & $\begin{array}{l}\text { Season } \\
2015\end{array}$ & $\begin{array}{c}\text { Season } \\
2016\end{array}$ \\
\hline \multirow{5}{*}{ MW } & $\mathrm{T}_{1}$ & $24.29 \mathrm{~d}$ & $25.18 \mathrm{e}$ & $18.66 \mathrm{~cd}$ & $19.33 \mathrm{~d}$ & $19.06 \mathrm{bc}$ & $18.14 \mathrm{~d}$ \\
\hline & $\mathrm{T}_{2}$ & $25.39 \mathrm{c}$ & $26.44 d$ & $19.00 \mathrm{c}$ & $20.00 \mathrm{~cd}$ & 19.12abc & $19.44 \mathrm{c}$ \\
\hline & $\mathrm{T}_{3}$ & $28.18 \mathrm{a}$ & $30.33 \mathrm{a}$ & $21.66 \mathrm{a}$ & $23.33 \mathrm{a}$ & $20.69 \mathrm{a}$ & $22.18 \mathrm{a}$ \\
\hline & $\mathrm{T}_{4}$ & $27.41 \mathrm{~b}$ & $29.03 b$ & $20.66 b$ & $22.33 b$ & $20.52 \mathrm{ab}$ & $21.06 \mathrm{~b}$ \\
\hline & $\mathrm{T}_{5}$ & $26.07 \mathrm{c}$ & $28.15 \mathrm{c}$ & $20.00 \mathrm{~b}$ & $20.66 \mathrm{c}$ & $20.00 \mathrm{ab}$ & $20.37 \mathrm{~b}$ \\
\hline \multirow{5}{*}{ NMW } & $\mathrm{T}_{1}$ & $18.13 \mathrm{i}$ & $20.07 \mathrm{j}$ & $13.33 \mathrm{~h}$ & $13.33 \mathrm{~h}$ & $13.65 \mathrm{e}$ & $12.66 \mathrm{~h}$ \\
\hline & $\mathrm{T}_{2}$ & $19.22 \mathrm{~h}$ & $21.20 \mathrm{i}$ & $14.33 \mathrm{~g}$ & $15.00 \mathrm{~g}$ & $14.33 \mathrm{de}$ & $14.11 \mathrm{~g}$ \\
\hline & $\mathrm{T}_{3}$ & $23.51 \mathrm{e}$ & $24.14 f$ & $18.00 \mathrm{de}$ & $18.00 \mathrm{e}$ & $17.85 \mathrm{c}$ & $17.40 \mathrm{de}$ \\
\hline & $\mathrm{T}_{4}$ & $22.30 \mathrm{f}$ & $23.15 \mathrm{~g}$ & $17.33 \mathrm{e}$ & $17.00 \mathrm{f}$ & $17.43 c$ & $16.56 \mathrm{e}$ \\
\hline & $\mathrm{T}_{5}$ & $20.43 \mathrm{~g}$ & $22.10 \mathrm{~h}$ & $15.66 \mathrm{f}$ & $16.33 \mathrm{f}$ & $15.71 \mathrm{~d}$ & $15.10 \mathrm{f}$ \\
\hline
\end{tabular}

Means having the same letter(s) in each column, row or interaction are not significantly different at 5\% level. MW: magnetic water, NMW: non-magnetized water. $* \mathrm{~T}_{1}$ : control treatment (spraying with water + molasses), $\mathrm{T}_{2}$ : compost tea + molasses, $\mathrm{T}_{3}$ : compost tea + licorice extract + molasses, $\mathrm{T}_{4}$ : compost tea + moringa extract + molasses, $\mathrm{T}_{5}$ : compost tea + algae extract + molasses.

Regarding compost tea with or without other growth stimulants, shoot length, the number of leaves/shoot and leaf area was affected significantly in both seasons. Whatever, $\mathrm{T}_{3}$ produced the highest shoot length, number of leaves/shoot in both seasons and leaf area in the second season, while there was insignificant difference between $T_{3}$ and $T_{4}$ in leaf area in the first season compared with other compost tea used. On the other

Egyptian J. Desert Res., 67, No. 2, 231-254 (2017) 
side, $T_{1}$ was the lowest in shoot length, number of leaves/shoot and leaf area in both seasons.

The data of the interaction between MW and compost tea with or without other growth stimulants treatments showed that, $\mathrm{T}_{3}$ under $\mathrm{MW}$ recorded the highest shoot length, number of leaves/shoot in both seasons and leaf area in the second season, while, there was insignificant affect among $\mathrm{T}_{2}, \mathrm{~T}_{3}, \mathrm{~T}_{4}$ and $\mathrm{T}_{5}$ in leaf area in the first season as compared with the other compost tea treatments. In addition, $\mathrm{T}_{1}$ under NMW recorded the lowest shoot length, the number of leaves/shoot and leaf area in both seasons.

These results may be due to the mechanism of magnetic field that enhance the activation of phytohormone, such as gibberellic acidequivalents, indole-3-acetic acid and trans-zeatin as well as activation of the bio-enzyme systems, which leads to the growth improvement and increased the yield (Maheshwari and Grewal, 2009 and Hozayn and Abdul Qados, 2010). It is also could be due to the magnetic water's ability to the direct effect on chemical and physical properties of the soil and then its indirect effect on the plant uptake of available nutrients as stated by Selim (2008) and Abou El- Yazied et al. (2012). Compost tea contains an abundance of micronutrients, which are absorbed through the foliar surface of plants. In addition, improving vegetative growth could be going to that behavior of licorice extract that containing mevalonic acid is similar to gibberellin. Furthermore, it could be due to that licorice extract contain protein and amino acid (Asparagin), monosaccharide (glucose, fructose, sucrose and maltose), lignins, tannins, starch, choline, phytosterols, different types of vitamins such as B1, B2, B3, B6, C, E, biotin, folic acid, pantothenic acid, many mineral compounds (aluminum, calcium, iron, magnesium, cobalt, zinc, phosphorus, sodium, silicone, potassium and stannous) and bitter principles (Fukai et al., 1998 and Arystanova et al., 2001).

The obtained results are in agreement with those of Bilalis et al. (2012), who stated that the electromagnetic fields could replace and activate hormones in vegetative growth of oregano as found by Podlesny et al. (2005), who recorded that magnetic treatment improved emergence and growth of two pea varieties. Also, Zuhair (2010) showed that spraying strawberry with licorice extract $(2 \mathrm{~g} / \mathrm{L})$ gave a significant increase in average leaf area, and Qaraghouli and Jalal (2005) found that spraying apple with licorice extract improved all growth parameters and Sheren and Eman (2015) proved that licorice extracts improved growth of Le-Conte "pear".

\section{Nitrogen, Phosphorus and Potassium Content in Leaves}

Data presented in table (7), show that all treatments were significantly effective on the peach content of leaf nitrogen, phosphorus and potassium in both seasons. However, MW gave higher significant leaf nitrogen, phosphorus and potassium content in both seasons comparing with 
NMW.

Table (7). Effect of magnetized water and compost tea on peach leaves content of nitrogen, phosphorus and potassium during 2015 and 2016 seasons.

\begin{tabular}{|c|c|c|c|c|c|c|c|}
\hline \multirow{2}{*}{\multicolumn{2}{|c|}{ Treatments }} & \multicolumn{2}{|c|}{$\mathbf{N}(\%)$} & \multicolumn{2}{|c|}{$\mathbf{P}(\%)$} & \multicolumn{2}{|c|}{$\mathrm{K}(\%)$} \\
\hline & & $\begin{array}{c}\text { Season } \\
2015\end{array}$ & $\begin{array}{c}\text { Season } \\
2016\end{array}$ & $\begin{array}{c}\text { Season } \\
2015\end{array}$ & $\begin{array}{c}\text { Season } \\
2016\end{array}$ & $\begin{array}{c}\text { Season } \\
2015 \\
\end{array}$ & $\begin{array}{c}\text { Season } \\
2016\end{array}$ \\
\hline \multicolumn{8}{|c|}{ Effect of water } \\
\hline MW & & $2.94 \mathrm{a}$ & $2.98 \mathrm{a}$ & $0.25 \mathrm{a}$ & $0.27 \mathrm{a}$ & $1.67 \mathrm{a}$ & $1.72 \mathrm{a}$ \\
\hline NMW & & $2.50 \mathrm{~b}$ & $2.57 \mathrm{~b}$ & $0.15 b$ & $0.16 \mathrm{~b}$ & $1.15 \mathrm{~b}$ & $1.17 \mathrm{~b}$ \\
\hline \multicolumn{8}{|c|}{ Effect of compost tea with or without some growth stimulants } \\
\hline$\overline{\mathrm{T}_{1}}$ & & $2.53 \mathrm{c}$ & $2.61 \mathrm{e}$ & $0.17 \mathrm{e}$ & $0.19 \mathrm{e}$ & $1.27 \mathrm{~d}$ & $1.29 \mathrm{e}$ \\
\hline $\mathrm{T}_{2}$ & & $2.65 \mathrm{~b}$ & $2.7 \mathrm{~d}$ & $0.19 \mathrm{~d}$ & $0.21 \mathrm{~d}$ & $1.34 \mathrm{c}$ & $1.38 \mathrm{~d}$ \\
\hline $\mathrm{T}_{3}$ & & $2.90 \mathrm{a}$ & $2.94 \mathrm{a}$ & $0.23 \mathrm{a}$ & $0.25 \mathrm{a}$ & $1.58 \mathrm{a}$ & $1.61 \mathrm{a}$ \\
\hline $\mathrm{T}_{4}$ & & $2.81 \mathrm{a}$ & $2.84 \mathrm{~b}$ & $0.22 b$ & $0.23 b$ & $1.47 \mathrm{~b}$ & $1.51 \mathrm{~b}$ \\
\hline $\mathrm{T}_{5}$ & & $2.71 \mathrm{~b}$ & $2.78 \mathrm{c}$ & $0.21 \mathrm{c}$ & $0.22 \mathrm{c}$ & $1.41 \mathrm{c}$ & $1.44 \mathrm{c}$ \\
\hline \multicolumn{8}{|c|}{ Effect of interaction between water and compost tea treatments } \\
\hline \multirow[b]{2}{*}{ Water } & \multirow[b]{2}{*}{$\begin{array}{l}\text { Compost } \\
\text { tea }\end{array}$} & \multicolumn{2}{|c|}{$\mathbf{N}(\%)$} & \multicolumn{2}{|c|}{$\mathbf{P}(\%)$} & \multicolumn{2}{|c|}{$\mathrm{K}(\%)$} \\
\hline & & $\begin{array}{c}\text { Season } \\
2015\end{array}$ & $\begin{array}{c}\text { Season } \\
2016\end{array}$ & $\begin{array}{c}\text { Season } \\
2015\end{array}$ & $\begin{array}{c}\text { Season } \\
2016\end{array}$ & $\begin{array}{c}\text { Season } \\
2015\end{array}$ & $\begin{array}{c}\text { Season } \\
2016\end{array}$ \\
\hline \multirow{5}{*}{ MW } & $\mathrm{T}_{1}$ & $2.76 \mathrm{~cd}$ & $2.80 \mathrm{~d}$ & $0.21 \mathrm{e}$ & $0.24 \mathrm{~d}$ & $1.54 \mathrm{c}$ & $1.56 \mathrm{~d}$ \\
\hline & $\mathrm{T}_{2}$ & $2.86 \mathrm{bc}$ & $2.90 \mathrm{c}$ & $0.23 \mathrm{~d}$ & $0.26 \mathrm{c}$ & $1.60 \mathrm{bc}$ & $1.67 \mathrm{c}$ \\
\hline & $\mathrm{T}_{3}$ & $3.10 \mathrm{a}$ & $3.16 \mathrm{a}$ & $0.29 \mathrm{a}$ & $0.31 \mathrm{a}$ & $1.83 \mathrm{a}$ & $1.86 \mathrm{a}$ \\
\hline & $\mathrm{T}_{4}$ & $3.06 \mathrm{a}$ & $3.06 \mathrm{~b}$ & $0.27 \mathrm{~b}$ & $0.28 \mathrm{~b}$ & $1.75 \mathrm{a}$ & $1.80 \mathrm{ab}$ \\
\hline & $\mathrm{T}_{5}$ & $2.93 \mathrm{~b}$ & $3.00 \mathrm{~b}$ & $0.26 \mathrm{c}$ & $0.27 \mathrm{~b}$ & $1.65 \mathrm{~b}$ & $1.73 \mathrm{bc}$ \\
\hline \multirow{5}{*}{ NMW } & $\mathrm{T}_{1}$ & $2.30 \mathrm{~g}$ & $2.43 \mathrm{~g}$ & $0.13 \mathrm{i}$ & $0.14 \mathrm{~h}$ & $1.01 \mathrm{~g}$ & $1.03 \mathrm{~h}$ \\
\hline & $\mathrm{T}_{2}$ & $2.45 \mathrm{f}$ & $2.50 \mathrm{f}$ & $0.15 \mathrm{~h}$ & $0.16 \mathrm{~g}$ & $1.08 \mathrm{f}$ & $1.10 \mathrm{~g}$ \\
\hline & $\mathrm{T}_{3}$ & $2.70 \mathrm{~d}$ & $2.73 d$ & $0.18 \mathrm{f}$ & $0.19 \mathrm{e}$ & $1.34 \mathrm{~d}$ & $1.36 \mathrm{e}$ \\
\hline & $\mathrm{T}_{4}$ & $2.56 \mathrm{e}$ & $2.63 \mathrm{e}$ & $0.17 \mathrm{fg}$ & $0.18 \mathrm{f}$ & $1.20 \mathrm{e}$ & $1.23 \mathrm{f}$ \\
\hline & $\mathrm{T}_{5}$ & $2.50 \mathrm{ef}$ & $2.56 \mathrm{ef}$ & $0.16 \mathrm{~g}$ & $0.17 \mathrm{fg}$ & $1.15 \mathrm{ef}$ & $1.16 \mathrm{fg}$ \\
\hline
\end{tabular}

Means having the same letter(s) in each column, row or interaction are not significantly different at 5\% level. MW: magnetic water, NMW: non-magnetized water. ${ }^{*} \mathrm{~T}_{1}$ : control treatment (spraying with water + molasses), $\mathrm{T}_{2}$ : compost tea + molasses, $\mathrm{T}_{3}$ : compost tea + licorice extract + molasses, $\mathrm{T}_{4}$ : compost tea + moringa extract + molasses, $\mathrm{T}_{5}$ : compost tea + algae extract + molasses.

In addition, leaf nitrogen, phosphorus and potassium content were affected significantly by compost tea with or without some growth stimulants in both seasons. $\mathrm{T}_{3}$ and $\mathrm{T}_{4}$ produced the highest leaf nitrogen content in the first season, While, $\mathrm{T}_{3}$ gave the highest leaf nitrogen content in the second season and the highest leaf phosphorus and potassium content in both seasons comparing with other used compost tea. While, $\mathrm{T}_{1}$ gave the lowest leaf nitrogen, phosphorus and potassium content in both seasons.

The interaction between magnetized water and compost tea treatments indicated that, $\mathrm{T}_{3}$ and $\mathrm{T}_{4}$ under $\mathrm{MW}$ recorded the highest leaf 
nitrogen content in the first season and leaf potassium content in both seasons. While, $\mathrm{T}_{3}$ under MW recorded the highest value of leaf nitrogen content in the second season and leaf phosphorus content in both seasons. In addition, $\mathrm{T}_{1}$ under NMW recorded the lowest leaf nitrogen phosphorus and potassium content in both seasons.

The obtained results are in agreement with those of Aly et al. (2015), who found that magnetic water caused an increase in nitrogen, phosphorus, potassium, calcium, and magnesium in Valencia orange leaves. Also, Fayek et al. (2014) showed that foliar application of compost tea recorded the highest $\mathrm{N}, \mathrm{P}$ and $\mathrm{K}$ contents in pear leaves. In addition, AlHadethi et al. (2012), Sheren and Eman (2015) and Shakir and Rawi (2017), found that spraying licorice extract on pear increased leaves nitrogen, potassium, iron and zinc content.

\section{Iron, Zinc, Copper and Manganese Content in Leaves}

It is evident from the data in table (8), that iron, zinc, copper and manganese content in leaves was significantly affected by all treatments in both seasons. However, MW gave the higher significant leaf iron (54.83 ppm in the $1^{\text {st }}$ and $58.85 \mathrm{ppm}$ in the $2^{\text {nd }}$ season), zinc $\left(20.73 \mathrm{ppm}\right.$ in the $1^{\text {st }}$ and $22.56 \mathrm{ppm}$ in the $2^{\text {nd }}$ season $)$, copper $\left(6.05 \mathrm{ppm}\right.$ in the $1^{\text {st }}$ and $6.54 \mathrm{ppm}$ in the $2^{\text {nd }}$ season) and manganese (20.37 ppm in the $1^{\text {st }}$ and $22.54 \mathrm{ppm}$ in the $2^{\text {nd }}$ season) contents comparing with NMW in both seasons.

Leaf iron, zinc, copper and manganese content were affected significantly by compost tea treatments in both seasons. The treatment " $\mathrm{T}_{3}$ " produced the highest iron, zinc, copper and manganese content in leaves in both seasons. While, $T_{1}$ gave the lowest leaf iron, zinc, copper and manganese content in both seasons.

The data obtained from the interaction between of MW and compost tea treatments pointed that $\mathrm{T}_{3}$ under MW recorded the highest leaf iron, zinc, copper and manganese content in both seasons. In addition, $\mathrm{T}_{1}$ under NMW recorded the lowest leaf iron, zinc, copper and manganese content in both seasons.

The positive influence of these results in the tables ( 7 and 8 ) may be due to that electromagnetic fields modify the rate of ion transport across the plasma membrane or otherwise affect the structure of cell membrane lipid protein dynamics. This may cause the alteration in the permeability of the plasma membrane of plant roots (Stange et al., 2002). It could be due to the significant increase in the rate of water absorption (Taia et al., 2007). Noran et al. (1996) and Maheshwari and Grewal (2009) mentioned that plants absorb more water of MTW than non-treated, consequently they uptake more nutrients as a result of water molecules of MTW that are minute and small, which reflected on the yield and water productivity. These results exhibited that MTW played an important role in improving the availability of these elements to plants. Selim (2008) indicated that MTW has induced 
changes in the mobility of nutrient elements in root zone, which is different from one element to another according to element magnetic susceptibility. In addition, the treatment of magnetic water affected the absorption of calcium and phosphor in soil and the plants can easily absorb them and consequently increased their growth (Maheshwari and Grewal, 2009).

Table (8). Effect of magnetized water and compost tea on peach leaves content of iron, zinc, copper and manganese during 2015 and 2016 seasons.

\begin{tabular}{|c|c|c|c|c|c|c|c|c|c|}
\hline & & \multicolumn{2}{|c|}{ Fe (ppm) } & \multicolumn{2}{|c|}{ Zn (ppm) } & \multicolumn{2}{|c|}{ Cu (ppm) } & \multicolumn{2}{|c|}{ Mn (ppm) } \\
\hline & & $\begin{array}{c}\text { Season } \\
2015 \\
\end{array}$ & $\begin{array}{c}\text { Season } \\
2016 \\
\end{array}$ & $\begin{array}{c}\text { Season } \\
2015 \\
\end{array}$ & $\begin{array}{c}\text { Season } \\
2016 \\
\end{array}$ & $\begin{array}{c}\text { Season } \\
2015 \\
\end{array}$ & $\begin{array}{c}\text { Season } \\
2016 \\
\end{array}$ & $\begin{array}{c}\text { Season } \\
2015 \\
\end{array}$ & $\begin{array}{c}\text { Season } \\
2016 \\
\end{array}$ \\
\hline \multicolumn{10}{|c|}{ Effect of water } \\
\hline MW & & $54.83 \mathrm{a}$ & $58.85 \mathrm{a}$ & $20.73 a$ & $22.56 \mathrm{a}$ & $6.05 \mathrm{a}$ & $6.54 \mathrm{a}$ & $20.37 \mathrm{a}$ & $22.54 \mathrm{a}$ \\
\hline NMW & & $43.75 b$ & $46.26 \mathrm{~b}$ & $14.70 \mathrm{~b}$ & $16.87 \mathrm{~b}$ & $2.60 \mathrm{~b}$ & $3.97 \mathrm{~b}$ & $16.00 \mathrm{~b}$ & $17.05 \mathrm{~b}$ \\
\hline \multicolumn{10}{|c|}{ Effect of compost tea with or without some growth stimulants } \\
\hline $\mathbf{T}_{1}$ & & $45.24 \mathrm{e}$ & $48.61 \mathrm{e}$ & $15.76 \mathrm{e}$ & $17.8 \mathrm{e}$ & $3.45 \mathrm{~d}$ & $4.20 \mathrm{~d}$ & $16.58 \mathrm{e}$ & $17.72 \mathrm{e}$ \\
\hline$T_{2}$ & & $46.75 \mathrm{~d}$ & $50.75 d$ & $16.86 \mathrm{~d}$ & $18.80 \mathrm{~d}$ & $3.70 \mathrm{~d}$ & $4.78 \mathrm{c}$ & $17.33 d$ & $19.07 \mathrm{~d}$ \\
\hline $\mathbf{T}_{3}$ & & $53.68 \mathrm{a}$ & $56.76 \mathrm{a}$ & $19.78 \mathrm{a}$ & $21.57 \mathrm{a}$ & $5.28 \mathrm{a}$ & $6.45 \mathrm{a}$ & $19.98 \mathrm{a}$ & $21.87 \mathrm{a}$ \\
\hline $\mathbf{T}_{4}$ & & $51.77 \mathrm{~b}$ & $54.56 \mathrm{~b}$ & $18.59 b$ & $20.58 b$ & $4.77 b$ & $5.78 b$ & $18.92 b$ & $20.46 b$ \\
\hline $\mathbf{T}_{5}$ & & $49.02 \mathrm{c}$ & $52.10 \mathrm{c}$ & $17.59 \mathrm{c}$ & $19.81 \mathrm{c}$ & $4.42 \mathrm{c}$ & $5.09 \mathrm{c}$ & $18.13 \mathrm{c}$ & $19.86 \mathrm{c}$ \\
\hline \multicolumn{10}{|c|}{ Effect of interaction between water and compost tea treatments } \\
\hline \multirow[b]{2}{*}{ Water } & \multirow[b]{2}{*}{$\begin{array}{l}\text { Compost } \\
\text { tea }\end{array}$} & \multicolumn{2}{|c|}{ Fe (ppm) } & \multicolumn{2}{|c|}{ Zn (ppm) } & \multicolumn{2}{|c|}{$\mathrm{Cu}(\mathbf{p p m})$} & \multicolumn{2}{|c|}{ Mn (ppm) } \\
\hline & & $\begin{array}{c}\text { Season } \\
2015\end{array}$ & $\begin{array}{c}\text { Season } \\
2016\end{array}$ & $\begin{array}{c}\text { Season } \\
2015\end{array}$ & $\begin{array}{c}\text { Season } \\
2016\end{array}$ & $\begin{array}{c}\text { Season } \\
2015\end{array}$ & $\begin{array}{c}\text { Season } \\
2016\end{array}$ & $\begin{array}{c}\text { Season } \\
2015\end{array}$ & $\begin{array}{c}\text { Season } \\
2016\end{array}$ \\
\hline \multirow{5}{*}{ MW } & $\mathbf{T}_{1}$ & $49.85 \mathrm{e}$ & $55.13 d$ & $18.99 \mathrm{~d}$ & $20.55 d$ & $4.95 \mathrm{~d}$ & $5.41 \mathrm{de}$ & $18.61 d$ & $20.20 \mathrm{e}$ \\
\hline & $\mathbf{T}_{\mathbf{2}}$ & $51.18 \mathrm{~d}$ & $57.26 \mathrm{c}$ & $19.83 \mathrm{c}$ & $21.86 \mathrm{c}$ & $5.37 \mathrm{c}$ & $5.93 \mathrm{~cd}$ & $19.29 \mathrm{~d}$ & $21.77 \mathrm{~d}$ \\
\hline & $\mathbf{T}_{3}$ & $60.63 \mathrm{a}$ & $62.64 a$ & $22.82 \mathrm{a}$ & $24.26 \mathrm{a}$ & $7.26 \mathrm{a}$ & $7.95 \mathrm{a}$ & $22.48 \mathrm{a}$ & $25.16 \mathrm{a}$ \\
\hline & $\mathbf{T}_{4}$ & $57.96 \mathrm{~b}$ & $61.01 \mathrm{~b}$ & $21.73 b$ & $23.40 b$ & $6.47 \mathrm{~b}$ & $7.13 b$ & $21.27 b$ & $23.21 \mathrm{~b}$ \\
\hline & $\mathbf{T}_{5}$ & $54.55 \mathrm{c}$ & $58.21 \mathrm{c}$ & $20.30 \mathrm{c}$ & $22.73 b$ & $6.18 \mathrm{~b}$ & $6.30 \mathrm{c}$ & $20.23 c$ & $22.39 \mathrm{c}$ \\
\hline \multirow{5}{*}{ NMW } & $\mathbf{T}_{1}$ & $40.63 j$ & $42.10 \mathrm{i}$ & $12.54 \mathrm{~h}$ & $15.07 \mathrm{~h}$ & $1.95 \mathrm{~g}$ & $3.00 \mathrm{i}$ & $14.55 \mathrm{~h}$ & $15.25 \mathrm{i}$ \\
\hline & $\mathbf{T}_{2}$ & $42.31 \mathrm{i}$ & $44.23 \mathrm{~h}$ & $13.90 \mathrm{~g}$ & $15.73 \mathrm{~h}$ & $2.04 \mathrm{~g}$ & $3.62 \mathrm{~h}$ & $15.38 \mathrm{~g}$ & $16.38 \mathrm{~h}$ \\
\hline & $\mathbf{T}_{3}$ & $46.74 \mathrm{f}$ & $50.89 \mathrm{e}$ & $16.74 \mathrm{e}$ & $18.88 \mathrm{e}$ & $3.30 \mathrm{e}$ & $4.95 \mathrm{ef}$ & $17.48 \mathrm{e}$ & $18.59 \mathrm{f}$ \\
\hline & $\mathbf{T}_{4}$ & $45.59 \mathrm{~g}$ & $48.11 \mathrm{f}$ & $15.45 \mathrm{f}$ & $17.77 \mathrm{f}$ & $3.07 \mathrm{e}$ & $4.42 \mathrm{fg}$ & $16.57 \mathrm{f}$ & $17.70 \mathrm{~g}$ \\
\hline & $\mathbf{T}_{5}$ & $43.50 \mathrm{~h}$ & $45.99 \mathrm{~g}$ & $14.88 \mathrm{f}$ & $16.89 \mathrm{~g}$ & $2.66 \mathrm{f}$ & $3.88 \mathrm{gh}$ & $16.03 \mathrm{f}$ & $17.33 \mathrm{~g}$ \\
\hline & $\begin{array}{l}\text { Means ha } \\
\text { significan } \\
\text { water. *T } \\
\text { molasses, } \\
\text { extract }+\end{array}$ & ng the & me lette & s) in $\mathrm{e}$ & a cora & , row & $\begin{array}{l}\text { s), } T_{2}: c \\
\text { ompost } t\end{array}$ & $\begin{array}{l}\text { on are } n \\
\text { magnetiz } \\
\text { npost tea } \\
+ \text { morin }\end{array}$ & \\
\hline
\end{tabular}

\section{Fruit Length and Diameter}

Data presented in table (9) show that fruit length and diameter was significantly affected by all treatments in both seasons. However, MW gave a higher fruit length, diameter comparing with NMW in both seasons.

Egyptian J. Desert Res., 67, No. 2, 231-254 (2017) 
Table (9). Effect of magnetized water and compost tea on fruit length and fruit diameter of peach during 2015 and 2016 seasons.

\begin{tabular}{|c|c|c|c|c|c|}
\hline \multirow{2}{*}{\multicolumn{2}{|c|}{ Treatments }} & \multicolumn{2}{|c|}{ Fruit length $(\mathrm{cm})$} & \multicolumn{2}{|c|}{ Fruit diameter $(\mathbf{c m})$} \\
\hline & & $\begin{array}{c}\text { Season } \\
2015\end{array}$ & $\begin{array}{c}\text { Season } \\
2016\end{array}$ & $\begin{array}{c}\text { Season } \\
2015\end{array}$ & $\begin{array}{c}\text { Season } \\
2016\end{array}$ \\
\hline \multicolumn{6}{|c|}{ Effect of water } \\
\hline MW & & $5.66 \mathrm{a}$ & $5.80 \mathrm{a}$ & $4.48 \mathrm{a}$ & $4.64 \mathrm{a}$ \\
\hline NMW & & $4.62 \mathrm{~b}$ & $4.71 \mathrm{~b}$ & $3.90 \mathrm{~b}$ & $4.07 \mathrm{~b}$ \\
\hline \multicolumn{6}{|c|}{ Effect of compost tea with or without some growth stimulants } \\
\hline $\mathbf{T}_{1}$ & & $4.78 \mathrm{e}$ & $4.90 \mathrm{~d}$ & $3.98 \mathrm{e}$ & $4.11 \mathrm{e}$ \\
\hline$T_{2}$ & & $4.98 \mathrm{~d}$ & $5.03 \mathrm{c}$ & $4.10 \mathrm{~d}$ & $44.26 \mathrm{~d}$ \\
\hline$T_{3}$ & & $5.51 \mathrm{a}$ & $5.71 \mathrm{a}$ & $4.40 \mathrm{a}$ & $4.58 \mathrm{a}$ \\
\hline $\mathbf{T}_{4}$ & & $5.28 \mathrm{~b}$ & $5.36 \mathrm{~b}$ & $4.28 \mathrm{~b}$ & $4.48 b$ \\
\hline $\mathbf{T}_{5}$ & & $5.15 \mathrm{c}$ & $5.26 \mathrm{~b}$ & $4.20 \mathrm{c}$ & $4.33 \mathrm{c}$ \\
\hline \multicolumn{6}{|c|}{ Effect of interaction between of water and compost tea treatments } \\
\hline \multirow[b]{2}{*}{ Water } & \multirow{2}{*}{$\begin{array}{l}\text { Compost } \\
\text { tea }\end{array}$} & \multicolumn{2}{|c|}{ Fruit length $(\mathbf{c m})$} & \multicolumn{2}{|c|}{ Fruit diameter $(\mathbf{c m})$} \\
\hline & & $\begin{array}{c}\text { Season } \\
2015\end{array}$ & $\begin{array}{c}\text { Season } \\
2016\end{array}$ & $\begin{array}{c}\text { Season } \\
2015 \\
\end{array}$ & $\begin{array}{c}\text { Season } \\
2016\end{array}$ \\
\hline \multirow{5}{*}{ MW } & $T_{1}$ & $5.10 \mathrm{e}$ & $5.23 \mathrm{e}$ & $4.16 \mathrm{e}$ & $4.43 \mathrm{~d}$ \\
\hline & $\mathbf{T}_{2}$ & $5.40 \mathrm{~d}$ & $5.46 \mathrm{~d}$ & $4.36 \mathrm{~d}$ & $4.53 \mathrm{c}$ \\
\hline & $\mathbf{T}_{3}$ & $6.20 \mathrm{a}$ & $6.50 \mathrm{a}$ & $4.76 \mathrm{a}$ & $4.86 \mathrm{a}$ \\
\hline & $\mathbf{T}_{4}$ & $5.90 \mathrm{~b}$ & $6.00 \mathrm{~b}$ & $4.60 \mathrm{~b}$ & $4.76 \mathrm{~b}$ \\
\hline & $\mathbf{T}_{5}$ & $5.70 \mathrm{c}$ & $5.80 \mathrm{c}$ & $4.50 \mathrm{c}$ & $4.60 \mathrm{c}$ \\
\hline \multirow{5}{*}{ NMW } & $T_{1}$ & $4.46 \mathrm{~h}$ & $4.56 \mathrm{~h}$ & $3.80 \mathrm{i}$ & $3.80 \mathrm{~h}$ \\
\hline & $\mathbf{T}_{2}$ & $4.56 \mathrm{gh}$ & $4.60 \mathrm{gh}$ & $3.83 \mathrm{hi}$ & $4.00 \mathrm{~g}$ \\
\hline & $\mathbf{T}_{3}$ & $4.83 \mathrm{f}$ & $4.93 \mathrm{f}$ & $4.03 \mathrm{ef}$ & $4.30 \mathrm{e}$ \\
\hline & $\mathbf{T}_{4}$ & $4.66 \mathrm{fg}$ & $4.73 \mathrm{~g}$ & $3.96 \mathrm{fg}$ & $4.20 \mathrm{f}$ \\
\hline & $T_{5}$ & $4.60 \mathrm{gh}$ & $4.73 \mathrm{~g}$ & $3.90 \mathrm{gg}$ & $4.06 \mathrm{~g}$ \\
\hline
\end{tabular}

Means having the same letter(s) in each column, row or interaction are not significantly different at 5\% level. MW: magnetic water, NMW: non-magnetized water. ${ }^{*} \mathrm{~T}_{1}$ : control treatment (spraying with water + molasses), $\mathrm{T}_{2}$ : compost tea + molasses, $\mathrm{T}_{3}$ : compost tea + licorice extract + molasses, $\mathrm{T}_{4}$ : compost tea + moringa extract + molasses, $\mathrm{T}_{5}$ : compost tea + algae extract + molasses

Furthermore, fruit length and diameter were affected significantly by compost tea treatments in both seasons. $\mathrm{T}_{3}$ produced the highest fruit length $\left(5.51 \mathrm{~cm}\right.$ in the $1^{\text {st }}$ and $5.71 \mathrm{~cm}$ in the $2^{\text {nd }}$ season) and diameter $(4.40 \mathrm{~cm}$ in the $1^{\text {st }}$ and $4.58 \mathrm{~cm}$ in the $2^{\text {nd }}$ season). On the other side, $T_{1}$ gave the lowest fruit length $\left(4.78 \mathrm{~cm}\right.$ in the $1^{\text {st }}$ and $4.90 \mathrm{~cm}$ in the $2^{\text {nd }}$ season) and diameter ( $3.98 \mathrm{~cm}$ in the $1^{\text {st }}$ and $4.11 \mathrm{~cm}$ in the $2^{\text {nd }}$ season).

The obtained data from the interaction between the MW and compost tea treatments cleared that, $\mathrm{T}_{3}$ under $\mathrm{MW}$ recorded the highest fruit length and diameter in both seasons. In addition, $\mathrm{T}_{1}$ and $\mathrm{T}_{2}$ under NMW recorded the lowest fruit length and diameter in both seasons. 


\section{Fruit Volume, Weight, Flesh Weight and Fruit Flesh Ratio}

The results in tables (10) show that fruit volume, weight, flesh weight and fruit flesh ratio (pulp weight/fruit weight) were significantly affected by all treatments in both seasons. However, MW gave the best fruit volume $\left(54.38 \mathrm{~cm}\right.$ in the $1^{\text {st }}$ and $58.00 \mathrm{~cm}$ in the $2^{\text {nd }}$ season), weight $(52.86 \mathrm{~g}$ in the $1^{\text {st }}$ and $56.48 \mathrm{~g}$ in the $2^{\text {nd }}$ season), flesh weight ( $48.17 \mathrm{~g}$ in the $1^{\text {st }}$ and $52.81 \mathrm{~g}$ in the $2^{\text {nd }}$ season) and fruit flesh ratio $\left(90.80 \%\right.$ in the $1^{\text {st }}$ and $93.26 \%$ in the $2^{\text {nd }}$ season).

On the other hand, fruit volume, weight, flesh weight and fruit flesh ratio (pulp weight/fruit weight) were affected significantly by different sources of compost tea in both seasons. $\mathrm{T}_{3}$ produced the highest fruit volume, fruit weight, flesh weight and fruit flesh ratio in both seasons. On the other side, $\mathrm{T}_{1}$ gave the lowest fruit volume, fruit weight, flesh weight and fruit flesh ratio in both seasons.

Moreover, the interactions between MW and different sources of compost tea cleared that $\mathrm{T}_{3}$ under MW recorded the highest fruit volume, fruit weight, flesh weight and fruit flesh ratio in both seasons. In addition, $\mathrm{T}_{1}$ under NMW recorded the lowest fruit volume, fruit weight, flesh weight and fruit flesh ratio in both seasons.

\section{Yield, Total Soluble Solids, Total Sugar and Total Acidity Content}

Data in table (11) indicated that yield, total soluble solids, total sugar and total acidity content were significantly affected by all treatments in both seasons. However, MW gave the best yield $\left(29.82 \mathrm{~kg}\right.$ in the $1^{\text {st }}$ and $32.35 \mathrm{~kg}$ in the $2^{\text {nd }}$ season), total soluble solids $\left(14.48 \%\right.$ in the $1^{\text {st }}$ and $14.84 \%$ in the $2^{\text {nd }}$ season), total sugar $\left(12.53 \%\right.$ in the $1^{\text {st }}$ and $12.69 \%$ in the $2^{\text {nd }}$ season) and decreased total acidity $\left(0.23 \%\right.$ in the $1^{\text {st }}$ and $0.22 \%$ in the $2^{\text {nd }}$ season $)$.

On the other hand, yield, total soluble solids, total sugar and total acidity content were affected significantly by compost tea with or without some growth stimulants in both seasons. $\mathrm{T}_{3}$ produced the highest yield, total soluble solids, total sugar and decreased total acidity in both seasons. On the other side, $\mathrm{T}_{1}$ decreased yield, total soluble solids, total sugar and increased total acidity in both seasons.

Egyptian J. Desert Res., 67, No. 2, 231-254 (2017) 
Table (10). Effect of magnetized water and compost tea on fruit volume, weight, flesh weight and fruit flesh ratio of peach during 2015 and 2016 seasons.

\begin{tabular}{|c|c|c|c|c|c|c|c|c|c|}
\hline \multirow{2}{*}{\multicolumn{2}{|c|}{ Treatments }} & \multicolumn{2}{|c|}{ Fruit volume $\left(\mathrm{cm}^{3}\right)$} & \multicolumn{2}{|c|}{ Fruit weight (g) } & \multicolumn{2}{|c|}{ Flesh weight (g) } & \multicolumn{2}{|c|}{ Fruit flesh ratio } \\
\hline & & $\begin{array}{c}\text { Season } \\
2015\end{array}$ & $\begin{array}{c}\text { Season } \\
2016\end{array}$ & $\begin{array}{c}\text { Season } \\
2015\end{array}$ & $\begin{array}{c}\text { Season } \\
2016\end{array}$ & $\begin{array}{c}\text { Season } \\
2015\end{array}$ & $\begin{array}{c}\text { Season } \\
2016\end{array}$ & $\begin{array}{c}\text { Season } \\
2015\end{array}$ & $\begin{array}{c}\text { Season } \\
2016\end{array}$ \\
\hline \multicolumn{10}{|c|}{ Effect of water } \\
\hline MW & & $54.38 \mathrm{a}$ & $58.00 \mathrm{a}$ & $52.86 \mathrm{a}$ & $56.48 \mathrm{a}$ & $48.17 \mathrm{a}$ & $52.81 \mathrm{a}$ & $90.80 \mathrm{a}$ & $93.26 \mathrm{a}$ \\
\hline NMW & & $36.14 b$ & $38.20 \mathrm{~b}$ & $34.87 \mathrm{~b}$ & $36.46 \mathrm{~b}$ & $27.27 \mathrm{~b}$ & $30.26 \mathrm{~b}$ & $77.58 \mathrm{~b}$ & $82.44 \mathrm{~b}$ \\
\hline \multicolumn{10}{|c|}{ Effect of compost tea with or without some growth stimulants } \\
\hline T1 & & $37.93 \mathrm{e}$ & $40.66 \mathrm{e}$ & $36.37 \mathrm{e}$ & $38.90 \mathrm{e}$ & $29.03 \mathrm{e}$ & $32.73 \mathrm{e}$ & $77.98 \mathrm{e}$ & $82.45 \mathrm{~d}$ \\
\hline $\mathbf{T} 2$ & & $42.04 d$ & $44.33 \mathrm{~d}$ & $40.60 d$ & $42.74 d$ & $33.94 d$ & $37.24 d$ & $82.19 \mathrm{~d}$ & $85.89 \mathrm{c}$ \\
\hline T3 & & $52.35 \mathrm{a}$ & $55.66 \mathrm{a}$ & $51.04 \mathrm{a}$ & $54.17 \mathrm{a}$ & $46.15 \mathrm{a}$ & $50.50 \mathrm{a}$ & $89.29 \mathrm{a}$ & $92.38 \mathrm{a}$ \\
\hline T4 & & $49.40 \mathrm{~b}$ & $51.16 \mathrm{~b}$ & $47.61 \mathrm{~b}$ & $49.56 \mathrm{~b}$ & $41.94 \mathrm{~b}$ & $45.06 \mathrm{~b}$ & $86.98 \mathrm{~b}$ & $89.93 b$ \\
\hline T5 & & $44.60 \mathrm{c}$ & $48.66 \mathrm{c}$ & $43.71 \mathrm{c}$ & $46.97 \mathrm{c}$ & $37.54 \mathrm{c}$ & $42.14 c$ & $84.51 \mathrm{c}$ & $88.61 \mathrm{~b}$ \\
\hline \multicolumn{10}{|c|}{ Effect of interaction between of water and compost tea treatments } \\
\hline \multirow[b]{2}{*}{ Water } & \multirow{2}{*}{$\begin{array}{l}\text { Compost } \\
\text { tea }\end{array}$} & \multicolumn{2}{|c|}{ Fruit volume $\left(\mathrm{cm}^{3}\right)$} & \multicolumn{2}{|c|}{ Fruit weight $(\mathrm{g})$} & \multicolumn{2}{|c|}{ Flesh weight $(\mathrm{g})$} & \multicolumn{2}{|c|}{ Fruit flesh ratio } \\
\hline & & $\begin{array}{c}\text { Season } \\
2015\end{array}$ & $\begin{array}{c}\text { Season } \\
2016\end{array}$ & $\begin{array}{c}\text { Season } \\
2015\end{array}$ & $\begin{array}{c}\text { Season } \\
2016\end{array}$ & $\begin{array}{c}\text { Season } \\
2015\end{array}$ & $\begin{array}{c}\text { Season } \\
2016\end{array}$ & $\begin{array}{c}\text { Season } \\
2015\end{array}$ & $\begin{array}{c}\text { Season } \\
2016\end{array}$ \\
\hline \multirow{5}{*}{ MW } & T1 & $45.74 \mathrm{e}$ & $49.66 \mathrm{e}$ & $44.26 \mathrm{e}$ & $47.49 \mathrm{e}$ & $38.26 \mathrm{e}$ & $42.82 \mathrm{e}$ & $86.43 \mathrm{~d}$ & $90.17 \mathrm{de}$ \\
\hline & T2 & $50.48 \mathrm{~d}$ & $53.66 \mathrm{~d}$ & $48.75 \mathrm{~d}$ & $52.00 \mathrm{~d}$ & $43.41 \mathrm{~d}$ & $47.66 \mathrm{~d}$ & $89.06 \mathrm{c}$ & $91.68 \mathrm{~cd}$ \\
\hline & T3 & $62.80 \mathrm{a}$ & $66.66 \mathrm{a}$ & $61.26 \mathrm{a}$ & $65.45 \mathrm{a}$ & $58.14 \mathrm{a}$ & $63.11 \mathrm{a}$ & $94.91 \mathrm{a}$ & $96.43 \mathrm{a}$ \\
\hline & T4 & $59.17 \mathrm{~b}$ & $61.33 b$ & $57.32 b$ & $60.19 b$ & $52.99 \mathrm{~b}$ & $56.86 \mathrm{~b}$ & $92.45 b$ & $94.45 \mathrm{ab}$ \\
\hline & $T_{5}$ & $53.71 \mathrm{c}$ & $58.66 \mathrm{c}$ & $52.71 \mathrm{c}$ & $57.27 \mathrm{c}$ & $48.04 \mathrm{c}$ & $53.61 \mathrm{c}$ & $91.15 b$ & $93.59 \mathrm{bc}$ \\
\hline \multirow{5}{*}{ NMW } & $T_{1}$ & $30.12 \mathrm{j}$ & $31.66 \mathrm{j}$ & $28.48 \mathrm{j}$ & $30.31 \mathrm{j}$ & $19.81 \mathrm{j}$ & $22.65 j$ & $69.52 \mathrm{~h}$ & $74.72 \mathrm{~h}$ \\
\hline & $\mathbf{T}_{2}$ & $33.60 \mathrm{i}$ & $35.00 \mathrm{i}$ & $32.46 \mathrm{i}$ & $33.49 \mathrm{i}$ & $24.46 \mathrm{i}$ & $26.82 \mathrm{i}$ & $75.32 \mathrm{~g}$ & $80.10 \mathrm{~g}$ \\
\hline & $\mathbf{T}_{3}$ & $41.89 \mathrm{f}$ & $44.66 \mathrm{f}$ & $40.83 \mathrm{f}$ & $42.89 \mathrm{f}$ & $34.17 f$ & $37.89 \mathrm{f}$ & $83.67 \mathrm{~d}$ & $88.33 \mathrm{e}$ \\
\hline & $\mathbf{T}_{41}$ & $39.62 \mathrm{~g}$ & $41.00 \mathrm{~g}$ & $37.89 \mathrm{~g}$ & $38.93 \mathrm{~g}$ & $30.89 \mathrm{~g}$ & $33.26 \mathrm{~g}$ & $81.52 \mathrm{e}$ & $85.41 \mathrm{f}$ \\
\hline & $\mathbf{T}_{5}$ & $35.50 \mathrm{~h}$ & $38.66 \mathrm{~h}$ & $34.71 \pi$ & $\mathrm{t} 36.67 \mathrm{~h}$ & $27.04 \mathrm{~h}$ & $30.67 \mathrm{~h}$ & $77.87 f$ & $83.63 \mathrm{f}$ \\
\hline
\end{tabular}

Means having the same letter(s) in each column, row or interaction are not significantly different at 5\% level. MW: magnetic water, NMW: non-magnetized water. ${ }^{*} \mathrm{~T}_{1}$ : control treatment (spraying with water + molasses), $\mathrm{T}_{2}$ : compost tea + molasses, $\mathrm{T}_{3}$ : compost tea + licorice extract + molasses, $\mathrm{T}_{4}$ : compost tea + moringa extract + molasses, $\mathrm{T}_{5}:$ compost tea + algae extract + molasses.

The obtained data from the interaction between MW and compost tea treatments indicated that $\mathrm{T}_{3}$ under MW recorded the highest yield, total soluble solids and total sugar, followed by $\mathrm{T}_{4}, \mathrm{~T}_{5}$ and $\mathrm{T}_{2}$, respectively, and decreased total acidity in both seasons. In addition, $\mathrm{T}_{1}$ under NMW was decreased yield, total soluble solids, total sugar and increased total acidity content in both seasons.

The positive effect in tables $(9,10$ and 11) may be due to that the application of magnetized irrigation water significantly increased the plant characteristics, chemical composition and availability of nutrients in the soil and increasing fruit quality and yield. The mechanism of magnetic field 
associated with the activation of phytohormone, such as gibberellic acidequivalents, indole-3-acetic acid and trans-zeatin as well as activation of the bio-enzyme systems, which play an important role in control the fruit drop and to improve the quality of fruit (Maheshwari and Grewal, 2009 and Hozayn and Abdul Qados, 2010). In addition, the enhancement of fruit quality and yield could be due to the effective components of licorice extract (i.e., nutritive, minerals and phytohormone) (Fukai et al., 1998 and Arystanova et al., 2001).

Table (11). Effect of magnetized water and compost tea on yield, total soluble solids, total sugar, total acidity content of peach during 2015 and 2016 seasons.

\begin{tabular}{|c|c|c|c|c|c|c|c|c|c|c|c|c|}
\hline \multirow{2}{*}{\multicolumn{2}{|c|}{ Treatments }} & \multicolumn{4}{|c|}{ Yield (kg/tree) } & \multicolumn{3}{|c|}{ T.S.S. (\%) } & \multicolumn{2}{|c|}{ Total sugar (\%) } & \multicolumn{2}{|c|}{ Acidity (\%) } \\
\hline & & \multicolumn{2}{|c|}{$\begin{array}{c}\text { Season } \\
2015\end{array}$} & \multicolumn{2}{|c|}{$\begin{array}{c}\text { Season } \\
2016\end{array}$} & \multicolumn{2}{|c|}{$\begin{array}{c}\text { Season } \\
2015\end{array}$} & $\begin{array}{c}\text { Season } \\
2016 \\
\end{array}$ & \multirow[t]{2}{*}{$\begin{array}{c}\text { Season } \\
2015 \\
\end{array}$} & \multirow[t]{2}{*}{$\begin{array}{c}\text { Season } \\
2016\end{array}$} & \multirow[t]{2}{*}{$\begin{array}{c}\text { Season } \\
2015 \\
\end{array}$} & \multirow[t]{2}{*}{$\begin{array}{c}\text { Season } \\
2016 \\
\end{array}$} \\
\hline \multicolumn{9}{|c|}{ Effect of water } & & & & \\
\hline MW & & & $82 \mathrm{a}$ & & & & $48 \mathrm{a}$ & $4.84 \mathrm{a}$ & $12.53 \mathrm{a}$ & $12.69 \mathrm{a}$ & $0.23 \mathrm{~b}$ & $0.22 \mathrm{~b}$ \\
\hline NMW & & & $60 \mathrm{~b}$ & & & & $00 \mathrm{~b}$ & $1.49 \mathrm{~b}$ & $8.98 \mathrm{~b}$ & $9.45 \mathrm{~b}$ & $0.27 \mathrm{a}$ & $0.29 \mathrm{a}$ \\
\hline \multicolumn{13}{|c|}{ Effect of compost tea with or without some growth stimulants } \\
\hline$T_{1}$ & & \multicolumn{2}{|c|}{$20.74 \mathrm{e}$} & \multicolumn{2}{|c|}{$23.91 \mathrm{e}$} & \multicolumn{2}{|c|}{$11.40 \mathrm{e}$} & $12.20 \mathrm{~d}$ & $9.40 \mathrm{e}$ & $9.97 \mathrm{~d}$ & $0.30 \mathrm{a}$ & $0.28 \mathrm{a}$ \\
\hline $\mathbf{T}_{2}$ & & \multirow{2}{*}{\multicolumn{2}{|c|}{$\begin{array}{l}22.92 \mathrm{~d} \\
28.84 \mathrm{a}\end{array}$}} & \multicolumn{2}{|c|}{$25.80 \mathrm{~d}$} & \multicolumn{2}{|c|}{$11.82 \mathrm{~d}$} & $12.54 \mathrm{~cd}$ & $9.80 \mathrm{~d}$ & $10.43 \mathrm{~d}$ & $0.25 \mathrm{~b}$ & $0.27 \mathrm{~b}$ \\
\hline $\mathbf{T}_{3}$ & & & & \multirow{2}{*}{\multicolumn{2}{|c|}{$\begin{array}{l}31.58 \mathrm{a} \\
30.06 \mathrm{~b}\end{array}$}} & \multicolumn{2}{|c|}{$14.18 \mathrm{a}$} & $14.42 \mathrm{a}$ & $12.20 \mathrm{a}$ & $12.43 \mathrm{a}$ & $0.22 \mathrm{e}$ & $0.23 \mathrm{e}$ \\
\hline $\mathbf{T}_{4}$ & & \multicolumn{2}{|c|}{$26.54 \mathrm{~b}$} & & & \multicolumn{2}{|c|}{$13.79 b$} & $13.85 b$ & $11.61 \mathrm{~b}$ & $11.58 \mathrm{~b}$ & $0.23 \mathrm{~d}$ & $0.25 \mathrm{~d}$ \\
\hline$T_{5}$ & & \multicolumn{2}{|c|}{$24.52 \mathrm{c}$} & \multicolumn{2}{|c|}{$27.78 \mathrm{c}$} & 12. & $51 \mathrm{c}$ & $.82 \mathrm{c}$ & $10.75 \mathrm{c}$ & $10.96 \mathrm{c}$ & $0.24 \mathrm{c}$ & $0.26 \mathrm{c}$ \\
\hline & & Effe & ct of & int & acti & h bot & ween of $\mathrm{v}$ & ater and $\mathrm{c}$ & compost te & a treatmer & & \\
\hline & & & & eld ( & $\mathrm{g} / \mathrm{tr}$ & & T.S & $\%(\%)$ & Total s & ugar (\%) & Acidit & $(\%)$ \\
\hline Water & & & $\begin{array}{r}\text { Sea } \\
20 \\
\end{array}$ & & $\begin{array}{r}\text { Sea } \\
20\end{array}$ & & $\begin{array}{c}\text { Season } \\
2015\end{array}$ & $\begin{array}{c}\text { Season } \\
2016 \\
\end{array}$ & $\begin{array}{c}\text { Season } \\
2015 \\
\end{array}$ & $\begin{array}{c}\text { Season } \\
2016\end{array}$ & $\begin{array}{c}\text { Season } \\
2015\end{array}$ & $\begin{array}{c}\text { Season } \\
2016 \\
\end{array}$ \\
\hline & $T_{1}$ & & 25.4 & & 28. & & $12.96 \mathrm{~d}$ & $13.95 \mathrm{c}$ & $10.96 \mathrm{~d}$ & $11.44 \mathrm{~cd}$ & $0.24 \mathrm{~d}$ & $0.25 \mathrm{~cd}$ \\
\hline & $\mathbf{T}_{2}$ & & 27.5 & & 30. & & $13.44 \mathrm{~d}$ & $14.04 \mathrm{c}$ & $11.29 \mathrm{~d}$ & $11.86 \mathrm{c}$ & $0.22 \mathrm{e}$ & $0.24 \mathrm{~d}$ \\
\hline MW & $T_{3}$ & & 34.5 & & 36. & & $16.32 \mathrm{a}$ & $16.33 \mathrm{a}$ & $14.34 \mathrm{a}$ & $14.26 \mathrm{a}$ & $0.20 \mathrm{f}$ & $0.19 \mathrm{~g}$ \\
\hline & $T_{4}$ & & 32.2 & & & & $15.66 \mathrm{~b}$ & $15.37 \mathrm{~b}$ & $13.55 \mathrm{~b}$ & $13.20 \mathrm{~b}$ & $0.21 \mathrm{f}$ & $0.21 \mathrm{f}$ \\
\hline & $T_{5}$ & & 29.2 & & 32. & & $14.03 \mathrm{c}$ & $14.50 \mathrm{c}$ & $12.51 \mathrm{c}$ & $12.70 \mathrm{~b}$ & $0.22 \mathrm{e}$ & $0.23 \mathrm{e}$ \\
\hline & $T_{1}$ & & 16.0 & & 19. & & $9.85 \mathrm{~g}$ & $10.45 \mathrm{f}$ & $7.85 \mathrm{~g}$ & $8.50 \mathrm{~g}$ & $0.31 \mathrm{a}$ & $0.32 \mathrm{a}$ \\
\hline & $\mathbf{T}_{2}$ & & 18.2 & & & & $10.21 \mathrm{~g}$ & $11.03 \mathrm{ef}$ & $8.32 \mathrm{~g}$ & $9.00 \mathrm{fg}$ & $0.30 \mathrm{~b}$ & $0.31 \mathrm{a}$ \\
\hline NMW & $T_{3}$ & & 23.1 & & 26. & & $12.03 \mathrm{e}$ & $12.51 \mathrm{~d}$ & $10.07 \mathrm{e}$ & 10.60de & $0.25 \mathrm{~d}$ & $0.26 \mathrm{c}$ \\
\hline & $\mathbf{T}_{4}$ & & 20.8 & & 25. & & $11.92 \mathrm{e}$ & $12.33 \mathrm{~d}$ & $9.66 \mathrm{e}$ & $9.96 \mathrm{e}$ & $0.27 \mathrm{c}$ & $0.28 \mathrm{~b}$ \\
\hline & $\mathbf{T}_{5}$ & & 19.7 & & 23. & & $11.00 \mathrm{f}$ & $11.15 \mathrm{e}$ & $9.00 \mathrm{f}$ & $9.22 \mathrm{f}$ & $0.28 \mathrm{c}$ & $0.29 b$ \\
\hline
\end{tabular}

Means having the same letter(s) in each column, row or interaction are not significantly different at 5\% level. MW: magnetic water, NMW: non-magnetized water. $* \mathrm{~T}_{1}$ : control treatment (spraying with water + molasses), $\mathrm{T}_{2}$ : compost tea + molasses, $\mathrm{T}_{3}$ : compost tea + licorice extract + molasses, $\mathrm{T}_{4}$ : compost tea + moringa extract + molasses, $\mathrm{T}_{5}$ : compost tea + algae extract + molasses.

The obtained results are in agreement with Esitken and Turan (2004) on cheery, Lepidium Sativum L. and tomato and Aly et al. (2015) on orange.

Egyptian J. Desert Res., 67, No. 2, 231-254 (2017) 
They clearly showed a gradual increase in fruits quality and yield by using magnetic irrigation water. In addition, Fayek et al. (2014) showed that foliar compost tea on pear recorded the highest yield and better fruit quality. In addition, Qaraghouli and Jalal (2005) on apple and Hussein (2008) on date palm found that spraying with licorice extracts increased the fruit quality and yield.

\section{Effect of Magnetic Water Treatment on Water Properties}

Fig. (1) clears that there were slight changes in water-soluble salts, $\mathrm{pH}$, micronutrients and salts composition under the irrigation with $\mathrm{MW}$ treatment as compared with NMW. Also, there is no evidence for the change in the content of microelements $(\mathrm{Fe}, \mathrm{Zn}, \mathrm{Cu}$ and $\mathrm{Mn}$ ) before and after magnetized treatment. In spite of the ability in magnetic treatment of irrigation water to slightly decrease of salinity than in untreated water, however, the salinity categories of water in magnetic treatment still located at the same classes of untreated water. The reason of using magnetic devices is not for causing chemical change of the salts in the magnetic of water (only about 10\% decrease) (Hozien, 2014 and Stephen, 2013), but to enhance water's ability to affect directly the chemical and physical properties of the soil, then its indirectly effect on plant uptake of available nutrients (Selim, 2008 and Abou El-Yazied et al., 2012). The main properties of magnetized treated water are the reduction of water molecules stores within the water. When that water passes through the soil, it leads to positive charges in the chemical and physical properties i.e. reduces soil $\mathrm{EC}$ and $\mathrm{pH}$; improves the soil permeability, fastness water movement to dissolve soil salts and entails a better assimilation of nutrients, which become available to plant uptake (Grewal and Maheshwari, 2011).

\section{Effect of Magnetic Water Treatment on Soil Chemical Properties}

Fig. (2) indicates that there was a decrease in $\mathrm{EC}$ and $\mathrm{pH}$ in soil paste extract after using magnetic treatment. In respect of the essential elements for plants, i.e. $\mathrm{Ca}, \mathrm{Mg}, \mathrm{K}$ and $\mathrm{Na}$, the results revealed that magnetized treatment affected the solubility of these elements in the soil and decreased using magnetic water as compared to without magnetic water. It appears that water magnetizing treatment leads to the intensive reduction of soluble $\mathrm{Na}$ salts, meanwhile, the decrease of other elements ( $\mathrm{Ca}, \mathrm{Mg}$ and $\mathrm{K}$ ) is less than the decrease of $\mathrm{Na}$. In addition, $\mathrm{Fe}, \mathrm{Zn}, \mathrm{Cu}$ and $\mathrm{Mn}$ in soil were increased under water magnetic treatments.

These results could be due to that the dissolving properties of water increase when started with the magnetic field as the magnetic water has small molecules, less viscosity, faster water movement and permeability at soil pore (Amiri and Dadkhah, 2006 and Al-Khazan et al., 2011). In addition, Hilal et al. (2012) mentioned that total salts removal from the soil with magnetic treatment was greater by $24.39 \%$ compared with normal 
water. Furthermore, magnetic treatment removes the excess of soluble salts and leaches the salts far away from root zone (Hilal et al., 2012 and Abou El-Yazied et al., 2012). In addition, Al Khazan et al. (2011) and Abou ElYazied et al. (2012) showed that reduction in soil pH is due to the effect of magnetic field on organic matter in the soil, where it releases relatively greater of organic acids in the rhizosphere. In addition, magnetic treatments lead to an increase in all elements content, except sodium. This is because $\mathrm{Na}$ is paramagnetic elements, which have a small positive susceptibility to magnetic fields, while other elements are diamagnetic, which are slightly repelled by a magnetic field (Nave, 2008). Moreover, Maheshwari and Grewal (2009) and Hilal et al. (2012) recorded that there was an increase of $\mathrm{Ca}, \mathrm{Mg}, \mathrm{K}$ concentration in the plants. Selim (2008) indicated that magnetic treatment has induced changes in the mobility of nutrient elements in root zone, which there are differences from one element to another according to element magnetic susceptibility.

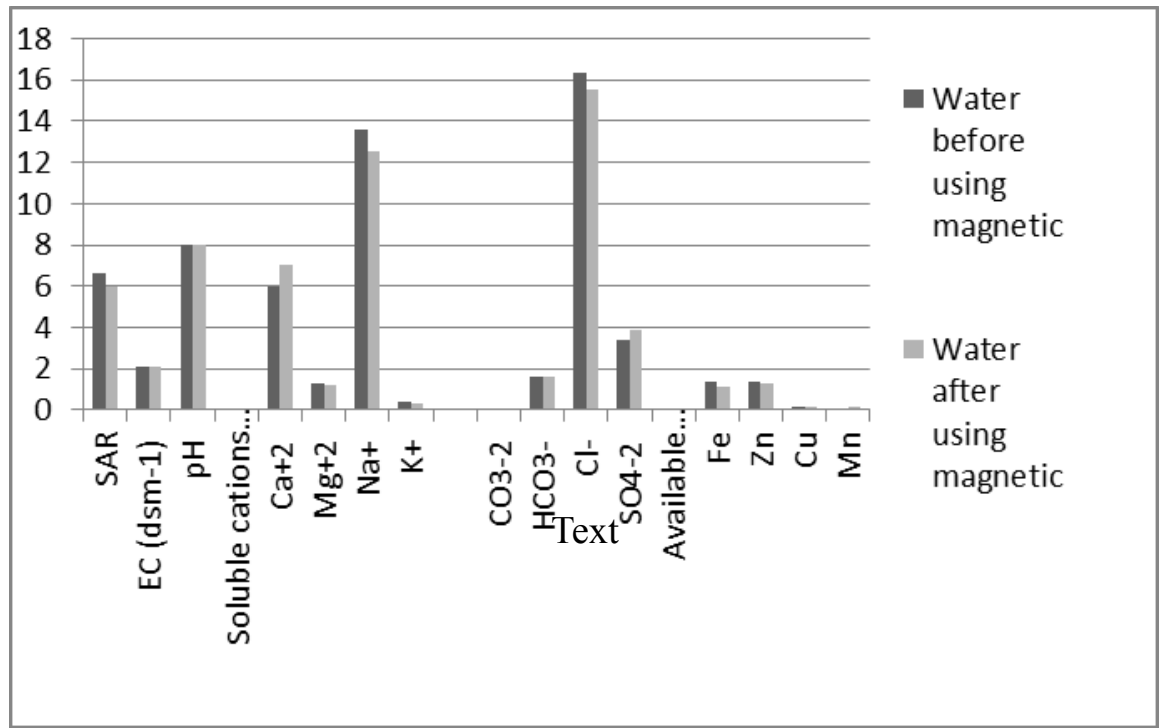

Fig. (1). Effect of magnetized treatment of the irrigation water on irrigation groundwater properties.

Egyptian J. Desert Res., 67, No. 2, 231-254 (2017) 


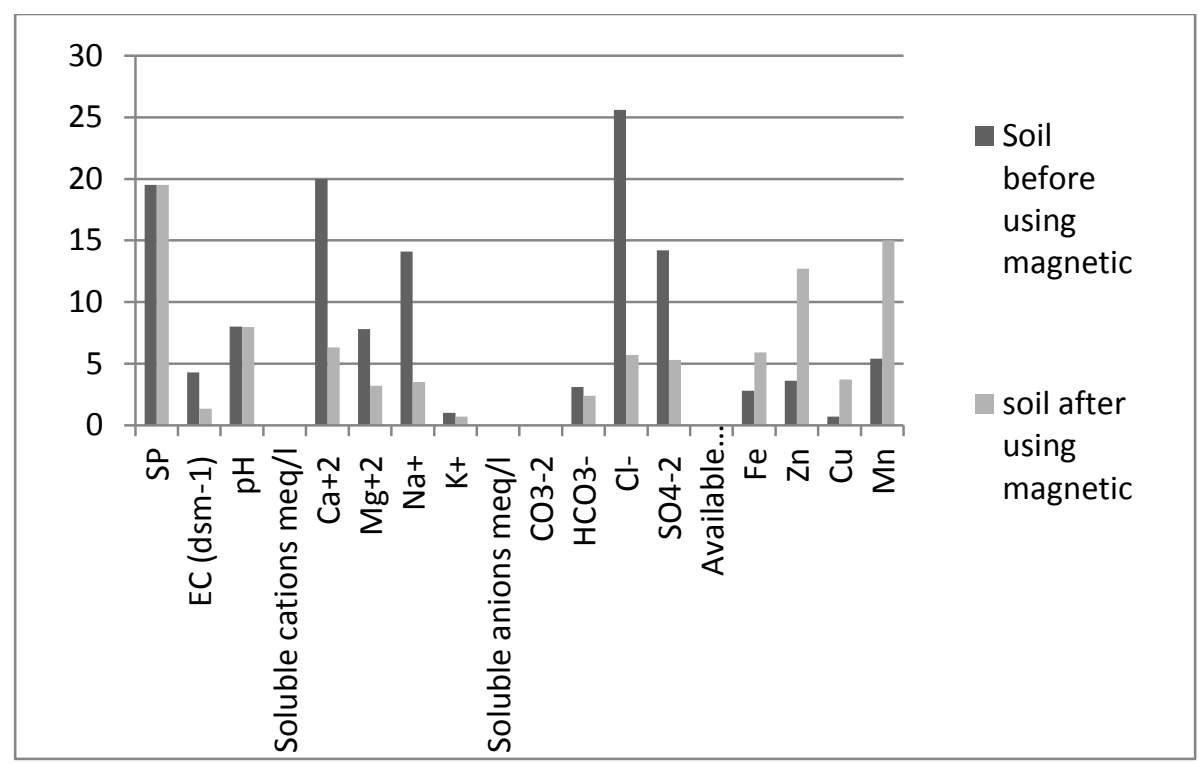

Fig. (2). Effect of magnetized treatment of the irrigation water on soil chemical properties.

\section{CONCLUSION}

All thing considered, it seems pertinent to indicate that under salinity stress, irrigation with magnetized water, coupled with the application of "compost tea + licorice extract $(4: 1, \mathrm{v}: \mathrm{v})+$ molasses" can be recommended as environmentally friendly treatment. Furthermore, this treatment can be used for various crops due to its high potentiality as well as the nutritive value.

\section{REFERENCES}

A.O.A.C. (1985). In "Official Methods of Analysis". Association of Official Agricultural Chemists, $14^{\text {th }}$ Ed.: Benjamin Franklin Station Washington, DC, USA, p. 490-510.

Abou El-Yazied, A., A.M. El-Gizawy, S.M. Khalf and A. El-Satar (2012). Effect of magnetic field treatments for seeds and irrigation water as well as $\mathrm{N}, \mathrm{P}$ and $\mathrm{K}$ levels on the productivity of tomato plants. J. Applied Sci. Res., 8 (4), 2088-2099.

Al-Hadethi, M.E.A., W.A.A. Al-Rawi and N.A. Jasim (2012). Pear seedlings response to sulfur and spraying licorice extract. Karbala University, Second Scientific Conference of the Faculty of Agriculture, p. 7783.

Al-Khazan, M., B.M. Abdullatif and N. Al-Assaf (2011). Effects of magnetically treated water on water status, chlorophyll pigments and 
some elements content of Jojoba (Simmondsia chinensis L.) at different growth stages. African Journal of Environmental Science and Technology, 5 (9): 722-731.

Aly, M.A., M. Ezz Thanaa, S.M. Osman and A.A. Mazek Abdelhamed (2015). Effect of magnetic irrigation water and some anti-salinity substances on the growth and production of valencia orange. Middle East Journal of Agriculture Research, 4: 88-98.

Amiri, M.C. and A.A. Dadkhah (2006). On reduction in the surface tension of water due to magnetic treatment. Colloids Surf. A: Physicochemical Eng. Aspects, 278, 252-255. Magnetics, 32: 58-65.

Arystanova, T., M. Irismetov and A. Sophekova (2001). Chromatographic determination of glycyrrhizinic acid in Glycyrrhiza glabra preparation. Chem. Nat. Com., 37: 89-91.

Babu, C. (2010). Use of magnetic water and polymer in agriculture. Ph.D., Agronomy D.W.S.R.Centre. Available online: http@waterforlif-net. OU/agric. /producefarming

Bilalis, D., N. Katsenios, A. Efthimiadou, A. Karkanis and P. Efthimiadis (2012). Investigation of pulsed electromagnetic field as a novel organic pre-sowing method on germination and initial growth stages of cotton. Electromag. Biol. Med., 31 (2): 143-150.

Brandifeld, E.G. and D. Spincer (1965). Determination of magnesium, calcium, zinc, iron, and copper by atomic adsorption spectroscopy. J. Food Agric. Sci., 16: 33-38.

Chouliaras, V., M. Tasioul, C. Chatzissavidis, I. Therios and T. Eleftheria (2009). The effects of a seaweed extract in addition to nitrogen and boron fertilization on productivity, fruit maturation, leaf nutritional status and oil quality of the olive (Olea europaea L.) cultivar Koroneiki. J. Sci. Food Agric., 89 (6): 984-988.

Clarke, G.M. and R.E. Kempson (1997). In "Introduction to the Design and Analysis of Experiments". (Arnold Ed.). A Member of the Holder Headline Group, London, UK.

Duncan, D.B. (1955). Multiple ranges and multiple F Test. Biometrics, 11: $1-42$.

Elham, Z. Abd El-Motty, F.M. Mohamed, S.M. El-Shiekh and M.M. AbdEl-Migeed (2010). Effect of algae extracts and yeast application on growth, nutritional status, yield and fruit quality of Keitte mango trees. Agric. Biol. J. N. Am., 1 (3): 421-429.

El-Sherbeny, S.E., M.Y. Khalil, M.S. Hussein and M.S. Aly (2007). Effect of sowing date and application of foliar fertilizers on the yield and chemical composition of rue (Ruta graveolens L.) herb. Herba Polonica, 54 (1): 47-56.

Eman, A. Abd El-Moniem and A.S.E. Abd-Allah (2008). Effect of green algae cells extracts as foliar spray on vegetative growth, yield and

Egyptian J. Desert Res., 67, No. 2, 231-254 (2017) 
berries quality of superior grapevines. Am. Euras. J. Agric. Environ. Sci., 4 (4): 427-433.

Esitken, A. and M. Turan (2004). Altering magnetic field effects and plant nutrient element composition of strawberry. Soil and Plant Science, 54: 135-139.

Fanous, N.E., Amira A. Mohamed and Kh.A. Shaban (2017). Effect of magnetic treatment for irrigation ground water on soil salinity, nutrients, water productivity and yield fruit trees at sandy soil. Egypt. J. Soil Sci., 57 (1): 113-123.

Fayek, M.A., T.A. Fayed, E.M. El-Fakhrani and Shaymmaa N. Sayed (2014). Yield and fruit quality of "Le-conte" pear trees as affected by compost tea and some antioxidants applications. Journal of Horticultural Science and Ornamental Plants, 6 (1): 1-8.

Fenwick, G., J. Lutomski and C. Nieman (1990). Glycyrrhiza glabra L. (Liquorice): Composition, uses, and analysis. Food Chem., 38 (2): 119-143.

Foidl, N., H.P.S. Makkar and K. Becker (2001). In "The Potential of Moringa oleifera for Agricultural and Industrial Uses. (Fuglie, L.J. Ed.). The Miracle Tree: The Multiple Attributes of Moringa, $p$. 45-76.

Fuglie, L.J. (2000). In "The Miracle Tree: Moringa oleifera: Natural Nutrition for the Tropics. The Multiple Attributes of Moringa, 172 pp.

Fukai, T., C. Baosheng, K. Maruno, Y. Migakawa, M. Konoshi, T. Nomura and B. Cai (1998). An isopernylated flavonone from Glycyrrhiza glabra and re-assay of liquorice phenols. Phytochem., 49: 20052013.

Grewal, H.S. and B.L. Maheshwari (2011). Magnetic treatment of irrigation water and snow-pea and chick-pea seeds enhances early growth and nutrient contents of seedlings. Bio-electro -magnetics, 32: 5865.

Hegab, M.Y., A.M.A. Sharawy and S.A.G. El-Saida (2005). Effect of algae extracts and mono potassium phosphate on growth and fruiting of Balady orange trees (Citrus sinensis). Proc. First Sci. Conf. Agric. Sci. Fac. of Agric., Assiut Univ., 1: 73-84.

Hendawy, S.F. (2008). Comparative study of organic and mineral fertilization on Plantago arenaria plant. J. of Appl. Sci. Res., 4: 500506.

Hilal, M.H., Y.M. El-Fakharaniy, S.S. Mabrouk, A.I. Mohamed and B. Ebead (2012). Effect of magnetic treated irrigation water on salt removal from a sandy soil and on the availability of certain nutrients. Int. J. Engineering App. Sci., 2 (2). 
Hozayn, M. and A.M. Abdul Qados (2010). Irrigation with magnetized water enhances growth, chemical constituent and yield of chick pea (Cicer arietinum L.). Agric. Biol. J. North America, 1 (4): 671-676.

Hozien, M. (2014). Opportunities of magnetic technology applications in Egyptian agriculture Forum. Future of Magnetic Agric. in Egypt, National Research Center.

Hussein, J.S. (2008). Effect of bagging and spraying licorice extract in the early maturity and improve the qualities of the fruit of the date palm Phoenix dactylifera L. cultivars Sayer and Mahallawy. Master, Faculty of Agriculture, University of Baghda, Iraq.

Jackson, N.L. (1967). In "Soil Chemical Analysis". Prentice-Hall Inc., Englewood Cliffs, New Jersy.

Jaswant, S., K.K. Sharma, S.S. Mann, R. Singh and G.P.S. Grewal (1994). Effect of different chemicals on yield and fruit quality of "Le Cont" pear. Acta Hort., 367: 210-213.

Maheshwari, B.L. and H.S. Grewal (2009). Magnetic treatment of irrigation water: Its effects on vegetable crop yield and water productivity. Agricultural Water Management, 96: 1229-1236.

Makkar, H.P.S. and K. Becker (1996). Nutritional value and ant nutritional components of whole and ethanol extracted Moringa oleifera leaves. Animal Feed Science and Technology, 63: 211-228.

Mansour, A.E., G.H. Cimpoies and F.F. Ahmed (2006). Application of algae extract and boric acid for obtaining higher yield and better fruit quality of Anna apple. Stiinta Agricola, 2: 14-20.

Mona, M. Abdalla (2013). The potential of Moringa oleifera extract as a biostimulant in enhancing the growth, biochemical and hormonal contents in rocket (Eruca vesicaria subsp. sativa) plants. International Journal of Plant Physiology and Biochemistry, 5(3): 42-49.

Nagar, P.K., R.I. Leyer and P.K. Sircar (2006). Cytokinins in developing fruits of Moringa pterigosperma Gaertn. Physiol. Plant, 55: 45-50.

Nave, C.L. (2008) Magnetic properties of solids. Hyper Phys., 15: 11-23.

Nimmi, V. and G. Medhu (2009). Effect of pre-sowing treatment with permanent magnetic field on germination and growth of Chili. Int. Agro Physics, 23: 195-198.

Noran, R., U. Shani and I. Lin (1996). The effect of irrigation with magnetically treated water on the translocation of mineral in the soil. Magnetic and Electrical Separation, 7: 109-122.

Page, A.L., Miller, R.H. and D.R. Keeney (1982). In "Methods of Soil Analysis". Parts 2. American Society of Agronomy, Madison, W.1.

Phiri, C. (2010). Influence of Moringa oleifera leaf extracts on germination and early seedling development of major cereals. Agric. Biol. J. North America, 1 (5): 774-777.

Egyptian J. Desert Res., 67, No. 2, 231-254 (2017) 
Podlesny, J., S. Pietruszewski and A. Podlesna (2005). Influence of magnetic stimulation of seeds on the formation of morphological features and yielding of the pea. Int. Agrophysics, 19: 61-68.

Qaraghouli, and H.K. Jalal (2005). The effect of spray extracts of garlic, licorice and AG3 in fruit set and fruit quality on Anna apples. Master, Faculty of Agriculture, University of Baghdad, Iraq.

Said, A.H.A.H., M.S. Hussein and A.A. Abd El-Kader (2010). Effect of nitrogen fertilizer and/or some foliar application on growth, herb yield, essential oil and chemical composition of dragonhead. Journal of Medicinal Food Plants, 2 (1): 12-28.

Selim, M.M. (2008). Application of magnetic technologies in correcting under ground brackish water for irrigation in the arid and semi-arid ecosystem. The $3^{\text {rd }}$ International Conference on Water Resources and Environment and the $1^{\text {st }}$ Arab Water Forum.

Shabani, L., A.A. Ehsanpour, G. Asghari and J. Emami (2009). Glycyrrhizin production by in vitro cultured Glycyrrhiza glabra elicited by methyl jasmonate and salicylic acid. Russian Journal of Plant Physiology, 56: 621-626.

Shakir, M.A. and W.A.A. Al-Rawi (2017). Effect of garlic and licorice root extract on leaves mineral and hormonal content of pear transplants. The Iraqi Journal of Agricultural Sciences, 48: 131-143.

Sheren, A. Abd El-Hamied and Eman I. El-Amary (2015). Improving growth and productivity of "pear" trees using some natural plants extracts under North Sinai conditions. Journal of Agriculture and Veterinary Science (IOSR-JAVS), 8 (1) Ver. I: 1-9.

Shibata, S. (2000). A drug over the millennia: Pharmacognosy, Chemistry, and Pharmacology of Licorice, Yakugaku zasshi-J. Pharmaceutical Society of Japan, 120: 849-862.

Stange, B.C., R. E. Rowland, B.I. Rapley and J.V. Podd (2002). Magnetic fields increase amino acid uptake into Vicia faba L. roots and alter ion movement across the plasma membrane. Bio electro magnetics, 23: 347-354.

Stephen, L. (2013). Magnetic water treatment and pseudo-Science. Available online: http://www./chem/1.com/CQ/ magsc9*an

Taia, C.Y., C. K. Wu and M.C. Chang (2007). Effects of magnetic field on the crystallization of $\mathrm{CaCO}_{3}$ using permanent magnets. J. Chem. Engin. Sci., 63: 5606-5612.

Zuhair, A.D. (2010). Effect of foliar spray of zinc and liquorice root extract on some vegetative and flowering growth parameters of two strawberry varieties (Fragaria $x$ ananassa Duch.) Mesopotamia Journal of Agriculture, 38: 152-151. 


\title{
إستخام الماء المفغطوشاي الكمبوست لتحسين إنتاجية الذوخ تحت
}

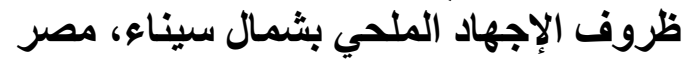

\author{
شيرين عادل عبد الحميد ووائل موسى غيث \\ قسم الإنتاج النباتي، مركز بحوث ووثل مودى الصحر اء، القاهرة، مصر
}

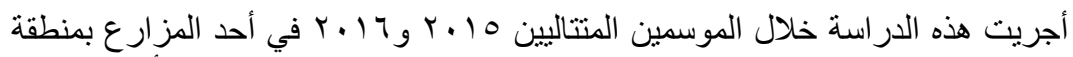

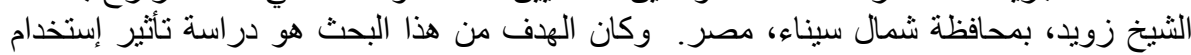

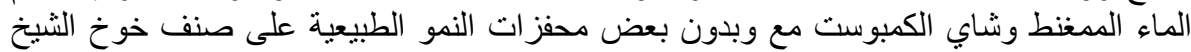

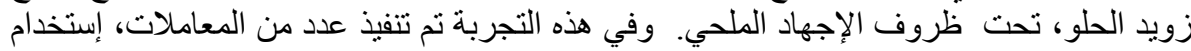

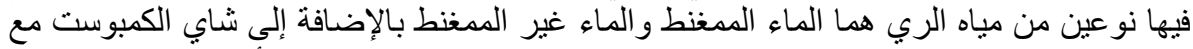

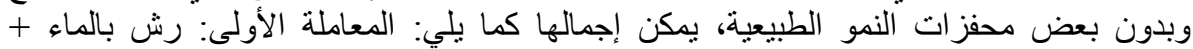

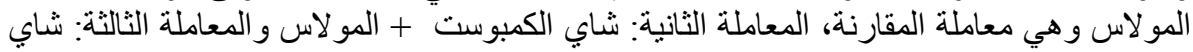

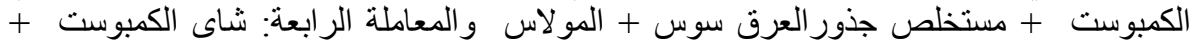

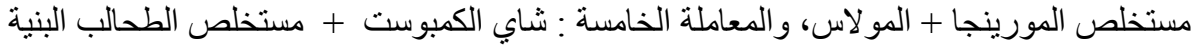

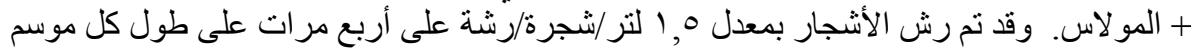

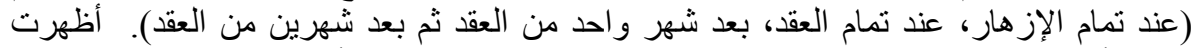

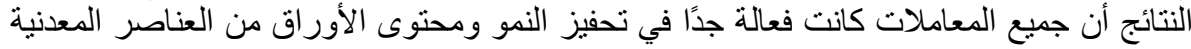

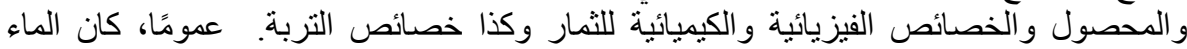

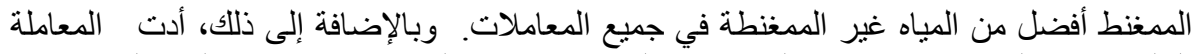

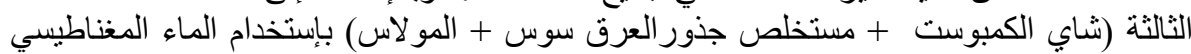

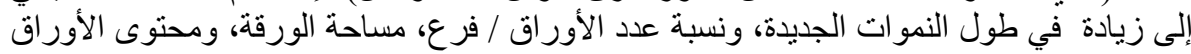

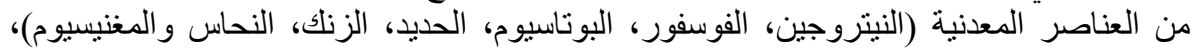

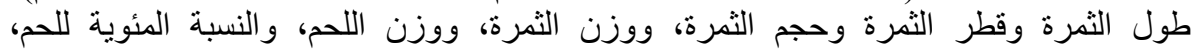

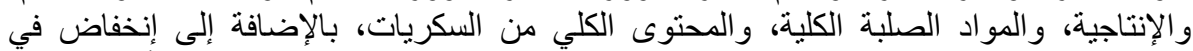

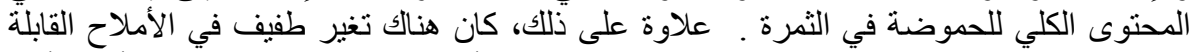

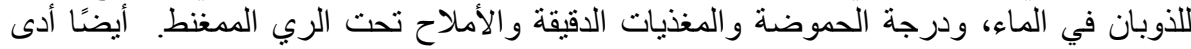

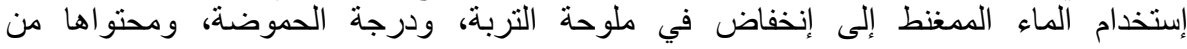
عناصر الكالسيوم، و المغنسيوم، و البوتاسيوم و الصوديوم ـ . وكذلك، ز زاد محتو الها من الحديد، و الزنلك،

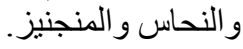

Egyptian J. Desert Res., 67, No. 2, 231-254 (2017) 